Gut and Liver, Vol. 10, No. 2, March 2016, pp. 177-203

\title{
Diagnosis and Management of Autoimmune Hepatitis: Current Status and Future Directions
}

\author{
Albert J. Czaja \\ Division of Gastroenterology and Hepatology, Mayo Clinic College of Medicine, Rochester, MN, USA
}

Autoimmune hepatitis is characterized by autoantibodies, hypergammaglobulinemia, and interface hepatitis on histological examination. The features lack diagnostic specificity, and other diseases that may resemble autoimmune hepatitis must be excluded. The clinical presentation may be acute, acute severe (fulminant), or asymptomatic; conventional autoantibodies may be absent; centrilobular necrosis and bile duct changes may be present; and the disease may occur after liver transplantation or with features that suggest overlapping disorders. The diagnostic criteria have been codified, and diagnostic scoring systems can support clinical judgment. Nonstandard autoantibodies, including antibodies to actin, $\alpha$-actinin, soluble liver antigen, perinuclear antineutrophil antigen, asialoglycoprotein receptor, and liver cytosol type 1 , are tools that can support the diagnosis, especially in patients with atypical features. Prednisone or prednisolone in combination with azathioprine is the preferred treatment, and strategies using these medications in various doses can ameliorate treatment failure, incomplete response, drug intolerance, and relapse after drug withdrawal. Budesonide, mycophenolate mofetil, and calcineurin inhibitors can be considered in selected patients as frontline or salvage therapies. Molecular (recombinant proteins and monoclonal antibodies), cellular (adoptive transfer and antigenic manipulation), and pharmacological (antioxidants, antifibrotics, and antiapoptotic agents) interventions constitute future directions in management. The evolving knowledge of the pathogenic pathways and the advances in technology promise new management algorithms. (Gut Liver 2016;10:177-203)

Key Words: Diagnosis; Atypical phenotypes; Autoantibodies; Treatment

\section{INTRODUCTION}

Autoimmune hepatitis has diverse clinical phenotypes, and this diversity has complicated its diagnosis and management. ${ }^{1-5}$ The classical perception of autoimmune hepatitis as a chronic inflammatory liver disease that affects mainly young white women has been expanded, ${ }^{6-8}$ and diagnostic boundaries now encompass patients of both genders ${ }^{9,10}$ all ages, ${ }^{11-14}$ and various ethnic groups. ${ }^{5,15}$ Patients may have acute, acute severe (fulminant), or asymptomatic presentations; they may lack conventional serological markers; and they may have atypical histological features. ${ }^{1-5}$ Autoimmune hepatitis must now be considered in all patients with acute and chronic hepatitis of undetermined cause, including patients with graft dysfunction after liver transplantation. ${ }^{16-18}$

Diagnostic criteria have been codified, and diagnostic scoring systems have been developed to supplement clinical judgment in difficult cases. ${ }^{19-21}$ The repertoire of serological markers has been expanded to improve diagnosis, and investigational assays are evolving that may have prognostic implications. ${ }^{22-31}$ Corticosteroids alone or in combination with azathioprine are the mainstays of treatment, ${ }^{17,18,32-34}$ but regimens, involving calcineurin inhibitors, mycophenolate mofetil, and budesonide, have emerged from diverse clinical experiences as alternative frontline and salvage therapies. ${ }^{35-51}$ Furthermore, the clarification of pathogenic molecular and cellular interactions have suggested new, testable, therapeutic interventions. ${ }^{34,52-60}$

The goals of this review are to describe the nonclassical clinical phenotypes of autoimmune hepatitis, present the diagnostic criteria that have been formalized for this disease, indicate the current and evolving serological repertoire, present guidelines for the administration of conventional treatment regimens, outline strategies for incorporating nonstandard drugs in the treatment of selected patients, and indicate the site-specific molecu-

Correspondence to: Albert J. Czaja

Division of Gastroenterology and Hepatology, Mayo Clinic College of Medicine, 200 First Street S.W., Rochester, MN 55905, USA

Tel: +1-507-284-2691, Fax: +1-507-284-0538, E-mail: czaja.albert@mayo.edu

Received on July 28, 2015. Accepted on November 4, 2015.

pISSN 1976-2283 eISSN 2005-1212 http://dx.doi.org/10.5009/gnl15352

@ This is an Open Access article distributed under the terms of the Creative Commons Attribution Non-Commercial License (http://creativecommons.org/licenses/by-nc/4.0) which permits unrestricted non-commercial use, distribution, and reproduction in any medium, provided the original work is properly cited. 
lar, cellular and pharmacological interventions that constitute future directions in the management of this disease.

\section{NONCLASSICAL CLINICAL PHENOTYPES}

\section{Acute and acute severe (fulminant) hepatitis}

An acute presentation occurs in 25\% to 75\% of patients with autoimmune hepatitis, ${ }^{61-65}$ and an acute severe (fulminant) presentation, characterized by the development of hepatic encephalopathy within 26 weeks of disease discovery, occurs in 3\% to 6\% of North American and European patients (Table 1). ${ }^{66,67}$ Each presentation can suggest an acute viral, toxic, or drug-induced liver injury, and each can delay recognition and proper treatment of autoimmune hepatitis.

Classical features of autoimmune hepatitis may be absent or less evident in patients with an acute severe (fulminant) presentation. Antinuclear antibodies (ANA) are undetected or weakly positive in $29 \%$ to $39 \%$ of patients, ${ }^{68,69}$ and serum immuno- globulin G (IgG) levels are normal in 25\% to 39\% of individuals (Table 1). ${ }^{25,69}$ Centrilobular hemorrhagic necrosis and massive or submassive liver necrosis dominate the histological findings in $86 \%$ of patients. ${ }^{67,68}$

Central perivenulitis with a prominent lymphoplasmacytic infiltrate and interface hepatitis supports the diagnosis of autoimmune hepatitis in 50\% to 90\% of patients with acute liver failure, ${ }^{67}$ and a histological assessment has been encouraged if liver tissue can be obtained safely. ${ }^{69,70}$ Heterogeneous hypoattenuated regions within the liver can be demonstrated by unenhanced computed tomography in 65\% of patients with autoimmune hepatitis and acute liver failure, and these findings are diseasespecific. $^{61,71}$

\section{Asymptomatic presentation}

Autoimmune hepatitis is asymptomatic in 25\% to 34\% of patients, and the diagnosis must be considered in all individuals with newly discovered mild liver test abnormalities (Table 1$)^{72,73}$

Table 1. Nonclassical Phenotypes of Autoimmune Hepatitis at Presentation

\begin{tabular}{|c|c|c|}
\hline Nonclassical phenotype & Features & Implications \\
\hline Acute onset & $\begin{array}{l}\text { Frequency, 25\%-75\% }{ }^{63,65} \\
\text { Newly developed or exacerbated } \\
\text { pre-existent disease }{ }^{61,63}\end{array}$ & $\begin{array}{l}\text { Can resemble acute viral, drug-induced, } \\
\text { toxic or ischemic injury }{ }^{61} \\
\text { Responds well to standard treatment }{ }^{61,63}\end{array}$ \\
\hline Acute severe (fulminant) onset & $\begin{array}{l}\text { Frequency, 3\%-6\% }{ }^{66,67} \\
\text { Onset encephalopathy } \leq 26 \text { weeks }{ }^{61} \\
\text { Classical features may be absent }{ }^{68} \\
\text { Centrilobular necrosis in } 86 \%{ }^{67} \\
\text { Lymphoplasmacytic infiltrates and interface } \\
\text { hepatitis in 50\%-90\% } 0^{67} \\
\text { Heterogeneous hypoattenuated regions } \\
\text { by unenhanced } \mathrm{CT}^{71}\end{array}$ & $\begin{array}{l}\text { Can resemble acute viral, drug-induced, } \\
\text { toxic or ischemic injury } \\
\text { Requires transplantation evaluation }{ }^{61} \\
\text { Variable response to corticosteroids and } \\
\text { possible complications (sepsis) }^{61}\end{array}$ \\
\hline Asymptomatic presentation & $\begin{array}{l}\text { Frequency, } 25 \%-34 \%{ }^{72,73} \\
\text { Histological features similar to symptomatic } \\
\text { patients }^{73} \\
\text { Become symptomatic in } 26 \%-70 \%{ }^{72,73} \\
\text { Survival without treatment possible }\end{array}$ & $\begin{array}{l}\text { Low frequency of resolution if untreated } \\
(12 \% \text { vs } 63 \%)^{74} \\
\text { Lower 10-year survival if untreated than } \\
\text { in treated severe AIH (67\% vs 98\% })^{74} \\
\text { Consider treating all patients }\end{array}$ \\
\hline Autoantibody-negative phenotype & $\begin{array}{l}\text { Scoring systems diagnostic, } 19 \%-22 \%{ }^{75} \\
\text { Acute liver failure possible }{ }^{83,84} \\
\text { Anti-SLA positive in } 9 \%-31 \%{ }^{26,83}\end{array}$ & $\begin{array}{l}\text { Steroid-responsive, } 67 \%-87 \% 0^{75,81} \\
\text { Test for nonstandard antibodies }{ }^{75} \\
\text { Exclude celiac disease }^{89,90,93}\end{array}$ \\
\hline Atypical histological patterns & $\begin{array}{l}\text { Centrilobular necrosis in } 29 \%{ }^{94} \\
\text { Bile duct injury or loss possible }{ }^{100,101}\end{array}$ & $\begin{array}{l}\text { May reflect severity and acuity of } \mathrm{AIH}^{94} \text { or } \\
\text { suggest other diagnoses }\end{array}$ \\
\hline Graft dysfunction posttransplant & $\begin{array}{l}\text { Recurrent AIH, 8\%-12\% after 1st year }{ }^{122} \\
\text { De novo AIH, 1\%-9\% within } 9 \text { years }{ }^{113} \\
\text { Anti-GSTT1 common in de novo } \mathrm{AIH}^{128}\end{array}$ & $\begin{array}{l}\text { Variable steroid response }^{113} \\
\text { Cirrhosis and graft failure possible }{ }^{113} \\
\text { Retransplantation required, 23\%-50\% }{ }^{113}\end{array}$ \\
\hline Overlap syndrome & $\begin{array}{l}\text { Mixed features of } \mathrm{AIH}+\mathrm{PBC} \text { or } \mathrm{PSC}^{102,107} \\
\text { "Paris criteria" for } \mathrm{AIH}+\mathrm{PBC}^{105,135}\end{array}$ & $\begin{array}{l}\text { Variable treatment response } e^{52,53} \\
\text { Frequently treated with steroids+UDCA }{ }^{130}\end{array}$ \\
\hline
\end{tabular}

CT, computed tomography; AIH, autoimmune hepatitis; anti-SLA, antibodies to soluble liver antigen; anti-GSTT1, antibodies to glutathione-Stransferase T1; PBC, primary biliary cholangitis; PSC, primary sclerosing cholangitis; UDCA, ursodeoxycholic acid. 
Symptoms develop in $26 \%$ to $70 \%$ of patients within 2 to 120 months (mean interval, 32 months), and histological findings, including the frequencies of moderate to severe interface hepatitis (87\% vs 93\%), periportal fibrosis ( $41 \%$ vs $41 \%$ ), and bridging fibrosis (39\% vs 48\%), are similar between asymptomatic and symptomatic individuals. ${ }^{73}$

Untreated patients with mild, asymptomatic, autoimmune hepatitis improve spontaneously less frequently (12\% vs $63 \%$, $\mathrm{p}=0.006$ ) and less completely than treated patients with severe symptomatic disease during $77 \pm 31$ months of observation, ${ }^{74}$ and they have a lower 10-year survival (67\% vs $98 \%, p=0.01) .{ }^{74}$ The uncertainty that mild autoimmune hepatitis remains mild compels the consideration of corticosteroid therapy in all patients with the diagnosis.

\section{Autoantibody-negative phenotype}

Patients with typical clinical and laboratory findings of autoimmune hepatitis may lack ANA, smooth muscle antibodies (SMA), and antibodies to liver kidney microsome type 1 (antiLKM1) (Table 1). ${ }^{75-77}$ The revised original scoring system of the International Autoimmune Hepatitis Group (IAIHG) has reclassified 34\% of patients with cryptogenic chronic hepatitis as definite or probable autoimmune hepatitis in one European study, ${ }^{78}$ and two North American studies have indicated that 19\% to $22 \%$ of patients with cryptogenic hepatitis can be categorized as autoimmune hepatitis by the scoring system of the IAIHG or by clinical judgment. ${ }^{80}$ Lower frequencies of autoantibodynegative autoimmune hepatitis (1\% to 5\%) have been reported in other studies applying different diagnostic criteria. ${ }^{81,82}$ Autoantibody-negative autoimmune hepatitis has been a cause of acute liver failure in 7\% of British patients ${ }^{83}$ and $24 \%$ of Japanese patients with acute severe (fulminant) presentations. ${ }^{84}$

Antinuclear antibodies and SMA may emerge later in the course of the disease ${ }^{85,86}$ or nonstandard autoantibodies may be detected and support the diagnosis. ${ }^{75}$ Antibodies to soluble liver antigen (anti-SLA) occur in $9 \%$ to $31 \%$ of these patients; $;^{26,83,87}$ atypical perinuclear antineutrophil cytoplasmic antibodies (pANCA) support the diagnosis in some patients; ${ }^{88}$ and immunoglobulin A (IgA) antibodies to tissue transglutaminase or endomysium may implicate celiac disease as the basis for the liver dysfunction in other patients. ${ }^{89-93}$ The absence of autoantibodies does not preclude the diagnosis of autoimmune hepatitis or a benefit from corticosteroid therapy. ${ }^{75,76,81}$

\section{Atypical histological patterns}

Interface hepatitis is the sine qua non of autoimmune hepatitis, but the spectrum of histological findings that can accompany interface hepatitis without invalidating the diagnosis is expanding. ${ }^{17}$ Centrilobular zone 3 necrosis is present in 29\% of patients with and without cirrhosis, ${ }^{94}$ and it may disappear in sequential tissue examinations (Table 1$).^{95}$ Centrilobular necrosis may be an acute or acute severe form of the disease, or it may reflect the spontaneous exacerbation of chronic disease. ${ }^{94,96,97}$ Patients with centrilobular necrosis respond well to conventional corticosteroid therapy, and they may normalize serum aminotransferase levels more frequently than patients without this histological finding (95\% vs 88\%). ${ }^{94}$

Bile duct injury may also be present with interface hepatitis. ${ }^{98-100}$ Biliary lesions that are isolated, unassociated with a cholestatic clinical syndrome, and unaccompanied by antimitochondrial antibodies (AMA) may constitute AMA-negative primary biliary cholangitis $(\mathrm{PBC})$ or small duct primary sclerosing cholangitis (PSC). ${ }^{100-104}$ Bile duct injury, including destructive cholangitis (florid duct lesions), in conjunction with AMA in patients with otherwise classical features of autoimmune hepatitis may constitute an overlap syndrome between autoimmune hepatitis and PBC. ${ }^{102,105-107}$ Bile duct injury manifested by ductopenia, portal fibrosis, and portal edema suggests an overlap syndrome with PSC. ${ }^{102}$

\section{Graft dysfunction after liver transplantation}

Autoimmune hepatitis can recur or develop de novo after liver transplantation, and it should be considered in all transplanted patients with graft dysfunction (Table 1). ${ }^{108-113}$ The frequency of recurrence ranges from $8 \%$ to $68 \%$, depending in part on the performance of liver tissue examinations by protocol or by clinical indication. ${ }^{113-118}$ Autoimmune hepatitis recurs in $8 \%$ to $12 \%$ after 1 year and 36\% to 68\% after 5 years (range, 2 months to 12 years after transplantation). ${ }^{113,119-122}$ De novo autoimmune hepatitis occurs in 1\% to $7 \%$ of patients (mainly children) 1 month to 9 years after transplantation for nonautoimmune liver disease. ${ }^{108,120,123-125}$

Diagnostic criteria for recurrent or de novo autoimmune hepatitis after liver transplantation have not been codified. ${ }^{113}$ Most patients have hypergammaglobulinemia, increased serum levels of IgG, conventional autoantibodies, and interface hepatitis with or without portal plasma cell infiltration. ${ }^{19,126,127}$ Adults with de novo autoimmune hepatitis may develop antibodies against glutathione-S-transferase T1 (anti-GSTT1). ${ }^{128}$ Recurrent and de novo autoimmune hepatitis are variably responsive to conventional corticosteroid therapy; cirrhosis develops in as many as $60 \%$; graft loss is possible; and retransplantation is required in $8 \%$ to $50 \% .^{113}$

\section{Overlap syndromes}

Patients with autoimmune hepatitis and features classically associated with PBC (AMA and histological features of bile duct injury or loss) and PSC (absence of AMA and cholangiographic changes of focal biliary strictures and dilations) have an overlap syndrome (Table 1). ${ }^{106,129,130}$ Patients with autoimmune hepatitis may also have a cholestatic syndrome in the absence of classical features of $\mathrm{PBC}$ and PSC. ${ }^{99}$ These patients may have an overlap syndrome with AMA-negative PBC or small duct PSC. ${ }^{102,103,107}$

The overlap syndromes occur in approximately $10 \%$ of pa- 
tients with otherwise classical features of autoimmune hepatitis. ${ }^{107}$ The major clinical consequence of the overlap syndromes is a variable response to conventional treatment regimens, and for this reason the diagnosis should be considered in all patients with refractory autoimmune hepatitis. ${ }^{106}$ Treatment is empiric and based on weak clinical evidence. Corticosteroids in combination with low dose ursodeoxycholic acid (13 to $15 \mathrm{mg} / \mathrm{kg}$ daily) is a common management strategy endorsed by the major liver societies. ${ }^{105,130-132}$

The gold standard for the diagnosis is clinical judgment, and the strongest independent predictor of an overlap syndrome is the liver tissue examination. ${ }^{133,134}$ The "Paris criteria" provide an objective basis for diagnosing the overlap syndrome between autoimmune hepatitis and $\mathrm{PBC},{ }^{105}$ and they have a sensitivity of $92 \%$ and specificity of 97\% compared to clinical judgment. ${ }^{135}$

\section{DIAGNOSTIC CRITERIA AND SCORING SYSTEMS}

Formalized diagnostic criteria ensure the application of a standardized diagnostic algorithm, ${ }^{19}$ and diagnostic scoring systems provide an evaluation template that can support the diagnosis in difficult cases. ${ }^{19-21}$ All diagnostic guidelines recommend the performance of a liver tissue examination to establish the diagnosis. ${ }^{17,19,33,136}$ Retrospective studies that propose elimination of the diagnostic tissue examination have failed to evaluate its importance in excluding patients with similar features but other diagnoses. ${ }^{137,138}$

\section{Codified diagnostic criteria of the IAIHG}

The diagnostic criteria of the IAIHG require the presence of compatible laboratory (serum aspartate [AST] and alanine ami-

Table 2. Comprehensive Diagnostic Scoring System of the International Autoimmune Hepatitis Group

\begin{tabular}{|c|c|c|c|}
\hline Clinical features & Points & Clinical features & Points \\
\hline \multirow[t]{3}{*}{ Female } & +2 & Average alcohol intake (g/day) & \\
\hline & & $<25$ & +2 \\
\hline & & $>60$ & -2 \\
\hline AP:AST (or ALT) ratio & & Histologic findings & \\
\hline$<1.5$ & +2 & Interface hepatitis & +3 \\
\hline $1.5-3.0$ & 0 & Lymphoplasmacytic infiltrate & +1 \\
\hline \multirow[t]{4}{*}{$>3.0$} & -2 & Rosette formation & +1 \\
\hline & & Biliary changes & -3 \\
\hline & & Other atypical changes & -3 \\
\hline & & None of above & -5 \\
\hline Serum globulin or IgG level above ULN & & Concurrent immune disease, including celiac disease & +2 \\
\hline$>2.0$ & +3 & Other autoantibodies & +2 \\
\hline $1.5-2.0$ & +2 & HLA DRB $1^{*} 03$ or DRB $1^{*} 04$ & +1 \\
\hline $1.0-1.5$ & +1 & & \\
\hline$<1.0$ & 0 & & \\
\hline ANA, SMA, or anti-LKM1 & & Response to corticosteroids & \\
\hline$>1: 80$ & +3 & Complete & +2 \\
\hline $1: 80$ & +2 & Relapse after drug withdrawal & +3 \\
\hline $1: 40$ & +1 & & \\
\hline$<1: 40$ & 0 & & \\
\hline AMA positive & -4 & & \\
\hline Hepatitis markers & & Aggregate score pretreatment & \\
\hline Positive & -3 & Definite autoimmune hepatitis & $>15$ \\
\hline Negative & +3 & Probable autoimmune hepatitis & $10-15$ \\
\hline Hepatotoxic drug exposure & & Aggregate score posttreatment & \\
\hline Positive & -4 & Definite autoimmune hepatitis & $>17$ \\
\hline Negative & +1 & Probable autoimmune hepatitis & $12-17$ \\
\hline
\end{tabular}

AP, alkaline phosphatase; AST, aspartate aminotransferase; ALT, alanine aminotransferase; IgG, immunoglobulin G; ULN, upper limit of the normal range; HLA, human leukocyte antigen; ANA, antinuclear antibodies; SMA, smooth muscle antibodies; anti-LKM1, antibodies to liver kidney microsome type 1; AMA, antimitochondrial antibodies.

Adapted from Alvarez F, et al. J Hepatol 1999;31:929-938, with permission of Elsevier BV and the European Association for the Study of the Liver. $^{19}$ 
notransferase [ALT] abnormalities, hypergammaglobulinemia, and increased serum IgG level), serological (ANA, SMA or antiLKM1 positivity) and histological findings (interface hepatitis with or without plasma cell infiltration). ${ }^{19}$ Diseases that can resemble autoimmune hepatitis must also be excluded by appropriate tests, and these include virus-related, drug-induced, alcoholic, hereditary (Wilson disease, hereditary hemochromatosis), metabolic (nonalcoholic fatty liver disease [NAFLD]), and immune-mediated cholestatic diseases (PBC and PSC). ${ }^{19}$ The designation of definite or probable autoimmune hepatitis reflects the level of confidence in the diagnosis based on the compatibility of the clinical features with classical autoimmune hepatitis. Two scoring systems are available for challenging cases. $^{19,20}$

\section{Revised original diagnostic scoring system of the IAIHG}

The revised original scoring system is a comprehensive template that evaluates 13 clinical categories and renders 27 possible grades (Table 2). ${ }^{19}$ This comprehensive scoring system was originally developed as a research tool by which to ensure the homogeneity of patient populations in clinical studies. ${ }^{139}$ It has emerged subsequently as a template by which to ensure the systematic evaluation of patients, and it can serve as a mechanism by which to bolster clinical judgment. ${ }^{21,140}$ The scoring system can accommodate deficiencies or inconsistencies in the clinical presentation and support the diagnosis in difficult cases by rendering a composite score before and after corticosteroid treatment.

\section{Simplified diagnostic scoring system of the IAIHG}

A simplified scoring system has been developed to ease clinical application. ${ }^{20}$ It evaluates four clinical categories and renders nine possible grades (Table 3). ${ }^{20}$ The original revised scoring system has greater sensitivity for autoimmune hepatitis (100\% vs $95 \%),{ }^{21}$ whereas the simplified scoring system has superior specificity (90\% vs 73\%) and accuracy (92\% vs 82\%), using clinical judgment as the gold standard. ${ }^{21}$ The simplified scoring system does not grade the treatment response, and this difference may contribute to its lower sensitivity. ${ }^{141}$ The revised original scoring system reclassifies patients with cryptogenic hepatitis as autoimmune hepatitis more commonly than the simplified scoring system (95\% vs 24\%), whereas the simplified scoring system excludes the diagnosis of autoimmune hepatitis more frequently in liver diseases that have concurrent immune manifestations $(83 \% \text { vs } 64 \%)^{21}$

\section{Limitations of the diagnostic scoring systems}

The diagnostic scoring systems have been extensively evaluated and refined by retrospective analyses of patients that have been characterized in single medical centers and diagnosed by experts in autoimmune liver disease. ${ }^{20,21,140-143}$ These characterizations have not followed a predefined protocol; pooled experiences have been limited; and comparative studies between medical centers have not been performed. ${ }^{141}$ Furthermore, assessments have not always been uniform or complete in each patient. ${ }^{20}$ Collaborative prospective clinical studies that adhere to a pre-established protocol and that ensure a uniform and complete assessment of each patient are necessary to validate the scoring systems.

The scoring systems have been applied beyond their original design and intention. They have been used inappropriately to determine the presence of autoimmune hepatitis in patients with PBC, ${ }^{144-146}$ and this application has been discouraged. ${ }^{130}$ The scoring systems have also been used but not validated in

Table 3. Simplified Diagnostic Scoring System of the International Autoimmune Hepatitis Group

\begin{tabular}{|c|c|c|c|}
\hline Category & Scoring elements & Results & Points \\
\hline \multirow[t]{4}{*}{ Autoantibodies } & ANA or SMA & $1: 40$ by IIF & +1 \\
\hline & ANA or SMA & $\geq 1: 80$ by IIF & +2 \\
\hline & Anti-LKM1 (alternative to ANA and SMA) & $\geq 1: 40$ by IIF & +2 \\
\hline & Anti-SLA (alternative to ANA, SMA and LKM1) & Positive & +2 \\
\hline \multirow[t]{2}{*}{ Immunoglobulins } & Immunoglobulin G level & $>\mathrm{ULN}$ & +1 \\
\hline & & $>1.1$ times ULN & +2 \\
\hline \multirow[t]{2}{*}{ Histological findings } & Interface hepatitis & Compatible features & +1 \\
\hline & & Typical features & +2 \\
\hline \multirow[t]{3}{*}{ Viral markers } & IgM anti-HAV, HBsAg, HBV DNA, HCV RNA & No viral markers & +2 \\
\hline & & Probable diagnosis & $\geq 6$ \\
\hline & & Definite diagnosis & $\geq 7$ \\
\hline
\end{tabular}

ANA, antinuclear antibodies; SMA, smooth muscle antibodies; anti-LKM1, antibodies to liver kidney microsome type 1; SLA, soluble liver antigen; IIF, indirect immunofluorescence; ULN, upper limit of the normal range; IgM, immunoglobulin M; HAV, hepatitis A virus; HBsAg, hepatitis B surface antigen; HBV, hepatitis B virus; DNA, deoxyribonucleic acid; HCV, hepatitis C virus; RNA, ribonucleic acid.

Adapted from Hennes EM, et al. Hepatology 2008;48:169-176, with the permission of John Wiley \& Sons, Inc. and the American Association for the Study of Liver Disease. ${ }^{20}$ 
patients with acute severe (fulminant) liver failure ${ }^{141,147}$ and in patients with graft dysfunction after liver transplantation. ${ }^{113}$

The performance parameters of the revised original and simplified scoring systems for autoimmune hepatitis are based on their compatibility with the gold standard of clinical judgment. ${ }^{19-21,140}$ The results of these scoring systems can never supersede clinical judgment, and they cannot make a clinically untenable diagnosis tenable. Misapplication of the scoring systems and overinterpretation of their results are major pitfalls that must be avoided.

\section{SEROLOGICAL MARKERS}

\section{Standard autoantibodies}

Antinuclear antibodies, SMA, and anti-LKM1 characterize most patients with autoimmune hepatitis, and they should be assessed in all candidates for the diagnosis (Table 4). ${ }^{17}$ Antinuclear antibodies and SMA are usually present in the absence of anti-LKM1, and anti-LKM1 are usually detected in the absence of ANA and SMA. ${ }^{148,149}$ This exclusivity has justified the designations of type 1 autoimmune hepatitis for those patients with ANA and/or SMA, and type 2 autoimmune hepatitis for those patients with anti-LKM1. ${ }^{148}$
The subtypes of autoimmune hepatitis have been associated with different age groups ${ }^{148}$ and genetic predispositions, ${ }^{150-153}$ but they have not been associated with major differences in treatment outcomes. ${ }^{17,33,154}$ Accordingly, the subtypes have not been endorsed as valid pathological entities. Indeed, among adults with autoimmune hepatitis, there have been no significant clinical, laboratory, histological, genetic or outcome differences to justify a designation of type 1 and type 2 autoimmune hepatitis. ${ }^{155}$

\section{1) Antinuclear antibodies and smooth muscle antibodies}

Antinuclear antibodies and SMA lack disease- and organspecificity (Table 4). Antinuclear antibodies are present in 80\% of patients with autoimmune hepatitis, and SMA occur in $63 \%{ }^{156}$ These antibodies also occur commonly in other liver diseases. Antinuclear antibodies are present in 20\% to 40\% of patients with alcoholic liver disease, NAFLD, chronic viral hepatitis, PBC or PSC. ${ }^{156-158}$ Smooth muscle antibodies occur in 3\% to $16 \%$ of patients with alcoholic liver disease, NAFLD, chronic hepatitis C, PBC or PSC. ${ }^{156-158}$ Each autoantibody has low sensitivity for the diagnosis (32\% for ANA and 16\% for SMA) when present as an isolated finding. ${ }^{156}$ The performance parameters of ANA and SMA are enhanced if both autoantibodies are present. The concurrence of ANA and SMA has a sensitivity of 43\%,

Table 4. Standard Antibodies for the Diagnosis of Autoimmune Hepatitis

\begin{tabular}{|c|c|c|}
\hline Standard antibodies & Antigenic target(s) & Clinical features \\
\hline \multirow[t]{8}{*}{ ANA } & Centromere, ribonucleoproteins, & Lacks organ and disease specificity ${ }^{156}$ \\
\hline & ribonucleoprotein complexes, histones ${ }^{160,161}$ & Present in $80 \%$ of adults with $\mathrm{AIH}^{156}$ \\
\hline & & Occurs in $20 \%-40 \%$ with non-AIH ${ }^{156-158}$ \\
\hline & & Sensitivity for AIH when isolated finding, $32 \%{ }^{156}$ \\
\hline & & Specificity for AIH when isolated finding, 76\% ${ }^{156}$ \\
\hline & & Diagnostic accuracy for AIH, 56\% ${ }^{156}$ \\
\hline & & Concurrent ANA and SMA most diagnostic $(74 \%)^{156}$ \\
\hline & & Titers can vary outside disease activity ${ }^{86,156}$ \\
\hline \multirow[t]{8}{*}{ SMA } & Filamentous (F) actin, 86\% ${ }^{162}$ & Lacks organ and disease specificity ${ }^{156}$ \\
\hline & Nonactin components, $14 \% 0^{162}$ & Present in $63 \%$ of adults with $\mathrm{AIH}^{156}$ \\
\hline & & Occurs in $3 \%-16 \%$ with non-AIH ${ }^{156-158}$ \\
\hline & & Sensitivity for AIH when isolated finding, 16\% $0^{156}$ \\
\hline & & Specificity for AIH when isolated finding, $96 \%{ }^{156}$ \\
\hline & & Diagnostic accuracy for $\mathrm{AIH}, 61 \%{ }^{156}$ \\
\hline & & Concurrent SMA and ANA most diagnostic $(74 \%)^{156}$ \\
\hline & & Titers $>1: 80$ associated with disease activity ${ }^{159}$ \\
\hline \multirow[t]{6}{*}{ Anti-LKM1 } & Cytochrome P450 2D6 ${ }^{167,168}$ & Present in 3\% of North American adults with $\mathrm{AIH}^{149}$ \\
\hline & & Detected in $14 \%-38 \%$ of British children with $\mathrm{AIH}^{11,163}$ \\
\hline & & Occurs in $0 \%-10 \%$ of chronic hepatitis $\mathrm{C}^{156,164-166}$ \\
\hline & & Low concurrence with SMA and ANA, 2\% ${ }^{156}$ \\
\hline & & High specificity (99\%), low sensitivity $(1 \%)^{156}$ \\
\hline & & Diagnostic accuracy in North American adults, $57 \%{ }^{156}$ \\
\hline
\end{tabular}


specificity of 99\%, and diagnostic accuracy of 74\% for autoimmune hepatitis. ${ }^{156}$

Antinuclear antibodies seem to be the most variable marker during the course of the disease, ${ }^{86}$ whereas SMA in titers $>1: 80$ are associated with laboratory (77\%) and histological (100\%) activity. ${ }^{159}$ Antinuclear antibodies are reactive against multiple nuclear components, including centromere, ribonucleoproteins, ribonucleoprotein complexes and histones, and 46\% of patients with ANA have multiple nuclear reactivities. ${ }^{160,161}$ Smooth muscle antibodies in autoimmune hepatitis are directed mainly against filamentous $(\mathrm{F})$ actin, but nonactin reactivities are present in $14 \%$ of patients with SMA. ${ }^{162}$

\section{2) Antibodies to liver kidney microsome 1}

Antibodies to LKM1 are present in 3\% of North American adults $^{149,156}$ and $14 \%$ to $38 \%$ of British children with autoimmune hepatitis (Table 4). ${ }^{11,163}$ They can also be demonstrated in $0 \%$ to $2 \%$ of North American patients ${ }^{156,164}$ and 10\% of European patients with chronic hepatitis C. ${ }^{165,166}$ Antibodies to LKM1 have a sensitivity of only $1 \%$ for autoimmune hepatitis in North American adults, but their specificity is 99\% and their diagnostic accuracy is $57 \%$. Only $2 \%$ of patients with ANA or SMA have anti-LKM1. ${ }^{156}$ The cytochrome mono-oxygenase, P450 2D6, is the target antigen of anti-LKM1. ${ }^{167,168}$

\section{Nonstandard autoantibodies}

The nonstandard autoantibodies constitute a repertoire of serological markers that can support or extend the diagnosis of autoimmune hepatitis to highly selected individuals in whom the standard biomarkers are insufficient to render a diagnosis. ${ }^{169-171}$ The presence of nonstandard autoantibodies can upgrade the diagnosis of autoimmune hepatitis by the revised original diagnostic scoring system of the IAIHG. ${ }^{17,19}$

\section{1) Antibodies to actin}

Antibodies to actin (antiactin) are directed against filamentous (F) actin, and they are present in $87 \%$ of patients with autoimmune hepatitis (Table 5). ${ }^{162,170,172}$ They also occur in diverse immune-mediated, nonliver diseases, including systemic lupus erythematosus, Sjögren syndrome, rheumatoid arthritis, celiac disease, diabetes, autoimmune thyroiditis and Crohn's disease. ${ }^{170}$ Antibodies to actin are a subset of SMA, and 86\% to 100\% of patients with autoimmune hepatitis and SMA have antiactin. ${ }^{162,173}$ Both SMA and antiactin are indirect markers of laboratory and histological activity in autoimmune hepatitis. ${ }^{159}$

Most patients with antiactin have at least SMA or other conventional autoantibodies, and the detection of antiactin is not critical for the diagnosis. ${ }^{162}$ Antibodies to actin have been associated with a higher frequency of death from hepatic failure or requirement for liver transplantation, but the prognostic implications of these antibodies are assay dependent. ${ }^{27,30,162,173-176}$ Multiple assays for antiactin are available, but none has been incorporated into a standard diagnostic repertoire. ${ }^{162,177}$

\section{2) Antibodies to $\alpha$-actinin}

$\alpha$-Actinins are cross-linking proteins that bind to actin and that are expressed as isoforms in muscle and nonmuscle cells. ${ }^{178}$ Antibodies to $\alpha$-actinin have been found by enzyme-linked immunosorbent assay (ELISA) in 42\% of patients with autoimmune hepatitis compared to $13 \%$ of patients with other liver diseases and 6\% of healthy blood donors (Table 5). ${ }^{27}$ Antibodies to $\alpha$-actinin are present in $66 \%$ of patients with autoimmune hepatitis who are positive for antifilamentous actin (anti-F actin), and the combination seems to be specific for the disease. ${ }^{27}$

Double reactivity to anti-F-actin and anti- $\alpha$-actinin seems to have prognostic implications. Patients with both antibodies have clinical and histological activity and a severe form of the disease characterized by an acute onset. ${ }^{27}$ Patients who respond to corticosteroid regimens have lower baseline levels of anti- $\alpha$ actinin than patients who relapse or respond incompletely, and the baseline level of anti- $\alpha$-actinin has been an independent predictor of treatment response. ${ }^{30}$ The assay for anti- $\alpha$-actinin is still investigational and not generally available. ${ }^{27,30}$

\section{3) Antibodies to soluble liver antigen}

Antibodies to soluble liver antigen (anti-SLA) are present in 7\% to $22 \%$ of patients with autoimmune hepatitis, and their occurrence varies among different ethnic groups (Table 5). ${ }^{26,31,87,179,180}$ Antibodies to soluble liver antigen seem to be least common in Japanese patients $(7 \%)^{26}$ and most common in German patients $(19 \%$ to $22 \%){ }^{26,87}$ The variability in serological expression may have a genetic basis, and anti-SLA have been associated with human leukocyte antigen (HLA) A1-B8 in Germany ${ }^{87}$ and HLA DRB $^{*} 0301$ in Britain ${ }^{25}$ and the United States. ${ }^{24}$

Antibodies to soluble liver antigen have high specificity for autoimmune hepatitis (99\%), ${ }^{179}$ and they have been the sole marker of autoimmune hepatitis in $14 \%$ to $20 \%$ of patients who would otherwise have been classified as cryptogenic hepatitis. ${ }^{159,180,181}$ They also have been associated with more severe histological findings, longer treatment requirement to suppress inflammatory activity, increased frequency of relapse after drug withdrawal, and higher frequency of liver transplantation or death from liver failure than patients without this marker. ${ }^{24-26,87,179}$ The target antigen of anti-SLA is a transfer ribonucleic acid (RNA)-protein complex, now designated as SEPSECS (Sep [0-phosphoserine] tRNA:Sec [selenocysteine] tRNA synthase). ${ }^{23,182,183}$ Antibodies to soluble liver antigen have also been closely associated with antibodies to ribonucleoprotein/Sjögren syndrome A antigen (anti-Ro/SSA), and the clinical implications of this tightly linked expression (96\% concurrence) remains unclear. $^{31,184-186}$

4) Atypical perinuclear antineutrophil cytoplasmic antibodies

Atypical pANCA are detected in 50\% to $92 \%$ of patients 
Table 5. Nonstandard Antibodies for the Diagnosis of Autoimmune Hepatitis

\begin{tabular}{|c|c|c|}
\hline Nonstandard antibodies & Antigenic target(s) & Clinical features \\
\hline \multirow[t]{5}{*}{ Antibodies to actin (antiactin) } & Filamentous $(\mathrm{F}) \operatorname{actin}^{162}$ & Present in $87 \%$ with $\mathrm{AIH}^{162,170,172}$ \\
\hline & \multirow[t]{4}{*}{ Nonactin components ${ }^{162}$} & Concurrent with SMA in 86\%-100\% with $\mathrm{AIH}^{162,173}$ \\
\hline & & SMA without antiactin in $14 \%$ with $\mathrm{AIH}^{162}$ \\
\hline & & Indirect marker of disease activity ${ }^{159,162}$ \\
\hline & & No standardized assay ${ }^{162,177}$ \\
\hline \multirow{4}{*}{$\begin{array}{l}\text { Antibodies to } \alpha \text {-actinin } \\
\text { (anti- } \alpha \text {-actinin) }\end{array}$} & \multirow[t]{4}{*}{$\alpha$-Actinin ${ }^{178}$} & Present in $42 \%$ of patients with $\mathrm{AIH}^{27}$ \\
\hline & & Antiactin+anti- $\alpha$-actinin associated with severity ${ }^{27}$ \\
\hline & & Baseline level predictive of treatment response ${ }^{30}$ \\
\hline & & Investigational assay not generally available ${ }^{27,30}$ \\
\hline \multirow{5}{*}{$\begin{array}{l}\text { Antibodies to soluble liver } \\
\text { antigen (anti-SLA) }\end{array}$} & \multirow{5}{*}{$\begin{array}{l}\text { Sep (0-phosphoserine) tRNA:Sec } \\
\text { (selenocysteine) tRNA synthase } \\
\text { (SEPSECS) }^{23,182,183}\end{array}$} & Present in 7\%-22\% with $\mathrm{AIH}^{26,31,87,179,180}$ \\
\hline & & Genetic association with HLA DRB $1^{*} 0301^{24,25}$ \\
\hline & & Associated with severity, response, relapse, survival ${ }^{24-26}$ \\
\hline & & Useful in diagnosing seronegative patients ${ }^{159,180,181}$ \\
\hline & & Specificity, 99\%, and sensitivity, $11 \%{ }^{179}$ \\
\hline \multirow{5}{*}{$\begin{array}{l}\text { Atypical perinuclear antineutrophil } \\
\text { cytoplasmic antibodies (pANCA) }\end{array}$} & \multirow[t]{5}{*}{$\beta$-Tubulin isotype $5^{189}$} & Cross reacts with precursor bacterial protein (FtsZ) ${ }^{189}$ \\
\hline & & Present in 50\%-92\% with typical $\mathrm{AIH}^{88,187-189}$ \\
\hline & & Absent in anti-LKM1-positive $\mathrm{AIH}^{190}$ \\
\hline & & Detected in CUC, PSC, PBC, minocycline injury $^{188,191,193}$ \\
\hline & & Useful in classifying seronegative $\mathrm{AIH}^{17,76,171,195}$ \\
\hline \multirow{5}{*}{$\begin{array}{l}\text { Antibodies to asialoglycoprotein } \\
\text { receptor (anti-ASGPR) }\end{array}$} & \multirow[t]{5}{*}{ Asialoglycoprotein receptor ${ }^{198,199}$} & Present in 67\%-88\% with $\mathrm{AIH}^{28,198-201}$ \\
\hline & & Occurs in other acute and chronic liver diseases ${ }^{198,203,204}$ \\
\hline & & Useful in classifying seronegative $\mathrm{AIH}^{205}$ \\
\hline & & Correlates with laboratory and histological activity ${ }^{206}$ \\
\hline & & May predict relapse and define treatment end points ${ }^{201,206}$ \\
\hline \multirow{4}{*}{$\begin{array}{l}\text { Antibodies to liver cytosol } \\
\text { type } 1 \text { (anti-LC1) }\end{array}$} & \multirow{4}{*}{$\begin{array}{l}\text { Formiminotransferase } \\
\text { cyclodeaminase }^{219-222}\end{array}$} & Present in 24\%-32\% of anti-LKM1-positive $\mathrm{AIH}^{208-210}$ \\
\hline & & Occurs in chronic hepatitis C and anti-LKM1 $1^{211-214}$ \\
\hline & & Useful in classifying seronegative $\mathrm{AIH}^{217,218}$ \\
\hline & & Rare in North American adults with $\mathrm{AIH}^{216}$ \\
\hline
\end{tabular}

AIH, autoimmune hepatitis; SMA, smooth muscle antibodies; HLA, human leukocyte antigen; anti-LKM1, antibodies to liver kidney microsome type 1; CUC, chronic ulcerative colitis; PSC, primary sclerosing cholangitis; PBC, primary biliary cholangitis.

with autoimmune hepatitis, often in high titer (mean titer, $11,410 \pm 1,875),{ }^{8,187-189}$ and serum titers are not associated with laboratory tests of disease activity (serum AST, IgG, and $\gamma$-globulin levels). ${ }^{88}$ Atypical pANCA exhibit some selectivity in that they are absent in anti-LKM1-positive autoimmune hepatitis, ${ }^{190}$ but they can occur in chronic ulcerative colitis, PSC, PBC, chronic hepatitis $\mathrm{C}$, and minocycline-induced autoimmune disease. $^{187,188,191-193}$

The primary target antigen has been characterized as a 50 $\mathrm{kDa}$ protein on the inner side of the nuclear envelope, ${ }^{191}$ and it has been identified as $\beta$-tubulin isotype $5 .^{189}$ Ninety-seven percent of patients with pANCA and autoimmune hepatitis have atypical pANCA, and 88\% of the pANCA-positive patients have reactivity to $\beta$-tubulin isotype $5 .{ }^{189}$ The pANCA of autoimmune hepatitis also cross-react with an evolutionary precursor bacte- rial protein, FtsZ, and 82\% of pANCA-positive patients with autoimmune hepatitis have reactivity to both proteins. ${ }^{189}$ These dual reactivities have justified speculation that intestinal microorganisms trigger an immune response that results in liver inflammation in genetically susceptible individuals. ${ }^{189,194}$

The assessment of atypical pANCA has been included in the comprehensive diagnostic scoring system for autoimmune hepatitis, ${ }^{19}$ and the autoantibodies may be useful in developing the diagnosis of autoimmune hepatitis in patients who are otherwise seronegative and classified as cryptogenic chronic hepatitis. ${ }^{17,76,171,195}$ The presence of atypical pANCA has been associated with cirrhosis ${ }^{187}$ and relapse after corticosteroid withdrawal in autoimmune hepatitis, ${ }^{196}$ but the prognostic implications of atypical pANCA in autoimmune hepatitis have not been sufficiently established to warrant their routine assessment. ${ }^{17,88,197}$ 


\section{5) Antibodies to asialoglycoprotein receptor}

Antibodies to the asialoglycoprotein receptor (anti-ASGPR) are present in $67 \%$ to $88 \%$ of patients with autoimmune hepatitis (Table 5). ${ }^{28,198-201}$ They occur in adults and children with autoimmune hepatitis, and they do not have an exclusive serological profile. ${ }^{202}$ Antibodies to the asialoglycoprotein receptor can be present in acute hepatitis A (57\%), acute hepatitis B (35\%), PBC (14\% to 100\%), chronic hepatitis C (14\%), alcoholic liver disease (8\%), and chronic hepatitis B (7\%). ${ }^{28,198,199,203,204}$ The lack of disease specificity has compromised the diagnostic function of anti-ASGPR, and the major value of this serological marker may be in the assessment of patients who are seronegative for the conventional markers of autoimmune hepatitis. ${ }^{205}$

Antibodies to asialoglycoprotein receptor can disappear during corticosteroid therapy, and the disappearance has been associated with histological resolution. ${ }^{206}$ Patients with anti-ASGPR during corticosteroid therapy also have a higher frequency of relapse after drug withdrawal than patients in whom antiASGPR has disappeared or never been expressed (88\% vs 33\%, $\mathrm{p}=0.01){ }^{201,206}$ These attributes suggest that anti-ASGPR may be useful in defining end points of treatment. ${ }^{28}$ The inability to standardize the assay for anti-ASGPR has been the major limitation to its broad clinical application. ${ }^{28,199,201,207}$

\section{6) Antibodies to liver cytosol type 1}

Antibodies to liver cytosol type 1 (anti-LC1) co-exist with anti-LKM1 in 24\% to 32\% of patients with anti-LKM1-positive autoimmune hepatitis (Table 5). ${ }^{208-210}$ They are also present in $12 \%$ to $33 \%$ of patients with chronic hepatitis C and anti-LKM1, ${ }^{21-214}$ and they occur infrequently in patients with autoimmune hepatitis and SMA and/or ANA. ${ }^{215}$ Antibodies to liver cytosol type 1 occur mainly in European children and young adults aged $\leq 20$ years, ${ }^{209,210}$ and they are rarely found in white North American adults. ${ }^{216}$ Antibodies to liver cytosol type 1 may be the sole markers of autoimmune hepatitis in patients seronegative for SMA, ANA, and anti-LKM1, ${ }^{217,218}$ but this diagnostic role may be limited, especially in North American adults in whom the frequency of anti-LC1 has been low. ${ }^{216}$ Formiminotransferase cyclodeaminase is a cytosolic enzyme that has been identified as the target antigen of anti-LC1. ${ }^{219-222}$

\section{STANDARD DRUG REGIMENS}

Prednisone or prednisolone alone or in combination with azathioprine is the mainstay therapy of autoimmune hepatitis (Table 6). ${ }^{17,33}$ Combination therapy is preferred as lower doses of corticosteroid can be administered when combined with azathioprine, and the frequency of corticosteroid-related side effects is lower (10\% vs $44 \%) .{ }^{223}$ Both regimens have otherwise similar outcomes. ${ }^{223}$ All patients with active autoimmune hepatitis are candidates for treatment regardless of symptom status (symp- tomatic versus asymptomatic) or disease severity (mild versus severe). ${ }^{34,74}$

Combination therapy is appropriate for most patients, especially those with an anticipated low tolerance for corticosteroids (individuals with obesity, diabetes, hypertension, osteopenia, or emotional instability). ${ }^{34}$ Monotherapy with corticosteroids is appropriate for patients with a known or anticipated intolerance of azathioprine (individuals with severe cytopenia [leukocyte count, $<2.5 \times 10^{9} / \mathrm{L}$; platelet count, $<50 \times 10^{9} / \mathrm{L}$ ], thiopurine methyltransferase deficiency [TPMT], or pregnancy) and for patients with acute severe autoimmune hepatitis or manifestations of acute liver failure. ${ }^{34}$

The immunosuppressive actions of azathioprine develop slowly over a 6-week period, ${ }^{224,225}$ and monotherapy with prednisone or prednisolone may have a more rapid action than combination therapy in patients with acute severe disease. ${ }^{49}$ Azathioprine is a category D drug for pregnancy in the United States, and congenital malformations have occurred in animal studies. ${ }^{226}$ Furthermore, azathioprine metabolites can pass the human placenta, ${ }^{227}$ and the drug has been of concern in the occurrence of human fetal complications. ${ }^{228}$ These concerns have been strongly counterbalanced by numerous studies in azathioprine-treated women with inflammatory bowel disease in whom the rarity or nonexistence of azathioprine-related fetal complications has been documented. ${ }^{184,229-233}$ Importantly, azathioprine is not an essential drug in the management of autoimmune hepatitis during pregnancy, and the drug can be replaced in pregnancy by an adjusted dose of prednisone or prednisolone. ${ }^{17,138}$

\section{Combination therapy with prednisone or prednisolone and azathioprine}

The preferred treatment regimen combining corticosteroids and azathioprine consists of an induction phase and a maintenance phase (Table 6). ${ }^{34}$ During the 4 -week induction phase, prednisone or prednisolone, $30 \mathrm{mg}$ daily, is administered for 1 week. The dose is then reduced to $20 \mathrm{mg}$ daily for 1 week and $15 \mathrm{mg}$ daily for 2 weeks. Azathioprine, $50 \mathrm{mg}$ daily, is given as a fixed dose during the entire induction phase. After 4 weeks of induction, the dose of prednisone or prednisolone is adjusted to $10 \mathrm{mg}$ daily. The dose of azathioprine is maintained at 50 $\mathrm{mg}$ daily. The maintenance phase is continued at fixed doses of prednisone or prednisolone, $10 \mathrm{mg}$ daily, and azathioprine, $50 \mathrm{mg}$ daily, until normalization of serum AST, ALT, bilirubin, and $\gamma$-globulin or IgG levels and resolution of the histological abnormalities. ${ }^{17}$ In Europe, prednisolone is preferred over prednisone, and it is commonly administered in a weight-based dose (up to $1 \mathrm{mg} / \mathrm{kg}$ daily) during the induction phase. Similarly, the dose of azathioprine is commonly weight-based (1 to $2 \mathrm{mg} / \mathrm{kg}$ daily). ${ }^{33,234,235}$

Blood leukocyte and platelet counts must be monitored throughout the induction and maintenance phases at 3 to 6 
Table 6. Standard Drug Regimens for Autoimmune Hepatitis

\begin{tabular}{|c|c|c|c|}
\hline \multirow{2}{*}{ Clinical situation } & \multicolumn{2}{|c|}{ Combination therapy } & \multirow{2}{*}{$\begin{array}{c}\text { Monotherapy } \\
\text { Prednisone or prednisolone }\end{array}$} \\
\hline & Prednisone or prednisolone & Azathioprine & \\
\hline \multirow[t]{4}{*}{ Treatment-naïve* } & $30 \mathrm{mg}$ daily $\times 1 \mathrm{wk}^{17,18,34}$ & 50 mg daily fixed dose $e^{17,18,34}$ & $60 \mathrm{mg}$ daily $\times 1 \mathrm{wk}^{17,18,34}$ \\
\hline & $20 \mathrm{mg}$ daily $\times 1 \mathrm{wk}$ & & $40 \mathrm{mg}$ daily $\times 1 \mathrm{wk}$ \\
\hline & 15 mg daily $\times 2 \mathrm{wk}$ & & $30 \mathrm{mg}$ daily $\times 2 \mathrm{wk}$ \\
\hline & 10 mg daily maintenance & & 20 mg daily maintenance \\
\hline \multirow[t]{8}{*}{ Treatment failure } & $30 \mathrm{mg}$ daily $\times 1 \mathrm{mo}^{253,256}$ & $150 \mathrm{mg}$ daily $\times 1 \mathrm{mo}^{253,256}$ & $60 \mathrm{mg}$ daily $\times 1 \mathrm{mo}^{253,256}$ \\
\hline & $20 \mathrm{mg}$ daily $\times 1 \mathrm{mo}$ if improved & $100 \mathrm{mg}$ daily $\times 1 \mathrm{mo}$ if improved & Reduce dose by $10 \mathrm{mg}$ for each \\
\hline & 10 daily maintenance if & 50 mg daily maintenance if & month of improvement until \\
\hline & improvement continues & improvement continues & 20 mg daily maintenance \\
\hline & Increase dose to last level of & Increase dose to last level of & Increase dose to last level of \\
\hline & improvement $\times 1$ mo if worsens & improvement $\times 1 \mathrm{mo}$ if worsens & improvement $\times 1$ mo if worsens \\
\hline & Increase to $30 \mathrm{mg}$ daily if & Increase to $150 \mathrm{mg}$ daily if & Increase to $60 \mathrm{mg}$ daily if \\
\hline & worsening continues & worsening continues & worsening continues \\
\hline \multirow[t]{5}{*}{ Incomplete response } & 10 mg daily ${ }^{253}$ & $2 \mathrm{mg} / \mathrm{kg}$ daily ${ }^{253}$ & 20 mg daily ${ }^{253}$ \\
\hline & Dose reductions to maintain & Fixed dose as steroid dose reduced & Dose reductions to lowest dose \\
\hline & normal or near-normal liver & or discontinued with goal of & possible to maintain normal or \\
\hline & tests with goal of drug & indefinite azathioprine & near-normal liver tests \\
\hline & withdrawal & maintenance & \\
\hline \multirow[t]{5}{*}{ Drug intolerance } & Decrease dose or & Decrease dose or discontinue & Decrease dose or discontinue \\
\hline & discontinue steroid $^{17,253}$ & azathioprine $^{17,253}$ & steroid $^{17,253}$ \\
\hline & Increase azathioprine dose to 100 & Increase dose of steroid as needed & Add azathioprine, 50 mg daily, \\
\hline & or $150 \mathrm{mg}$ daily if necessary & or cautiously consider mycophe- & and adjust dose \\
\hline & & nolate mofetil, 1-2 g daily ${ }^{41,45,46}$ & \\
\hline \multirow{5}{*}{$\begin{array}{l}\text { Relapse after drug } \\
\text { withdrawal }\end{array}$} & Resume original regimen until & Resume original regimen until & Resume original regimen for until \\
\hline & resolution of liver tests & resolution of liver tests & resolution of liver tests \\
\hline & Gradually withdraw and & Increase dose to $2 \mathrm{mg} / \mathrm{kg}$ daily and & Decrease steroid dose to lowest \\
\hline & discontinue as dose of & continue indefinitely $^{17,32,253}$ & level and maintain \\
\hline & azathioprine increased $^{17,253}$ & & indefinitely ${ }^{17,253,259}$ \\
\hline
\end{tabular}

*Treatment-naïve regimens in Europe commonly include prednisolone at $1 \mathrm{mg} / \mathrm{kg}$ daily and azathioprine at $1-2 \mathrm{mg} / \mathrm{kg}$ daily. ${ }^{33,234,235}$

month intervals. ${ }^{17}$ Progressive cytopenia warrants the reduction or discontinuation of azathioprine. The determination of TPMT activity prior to treatment can identify the $0.3 \%$ of the normal population with absent TPMT activity. ${ }^{236}$ These patients are at risk for azathioprine-induced myelosuppression. ${ }^{138,237}$ Routine genotyping or phenotyping for TPMT activity has not correlated closely with the occurrence of azathioprine toxicity except in those patients with absent enzyme. ${ }^{238-240}$ Close monitoring of the clinical and hematological findings has been emphasized for all patients receiving this medication. ${ }^{17}$

\section{Monotherapy with prednisone or prednisolone}

Monotherapy with prednisone or prednisolone involves a 4-week induction phase and then a fixed-dose maintenance phase (Table 6). ${ }^{17}$ During the 4 -week induction phase, prednisone or prednisolone, $60 \mathrm{mg}$ daily, is administered for 1 week. The dose is then reduced to $40 \mathrm{mg}$ daily for 1 week and 30 mg daily for 2 weeks. ${ }^{34}$ After 4 weeks of induction, the dose of prednisone or prednisolone is reduced to $20 \mathrm{mg}$ daily, and the regimen is maintained until resolution of clinical, laboratory and histological findings. ${ }^{34}$ An adjuvant program of regular weight-bearing exercise, vitamin D and calcium supplementation, and treatment with bisphosphonates (if justified by bone densitometry or clinical history of bone disease) may protect against progressive corticosteroid-related osteopenia. ${ }^{17}$

\section{Treatment duration}

Treatment is continued until normal laboratory tests and liver tissue. ${ }^{17}$ Normal liver tests are achieved in $66 \%$ to $91 \%$ of patients within 2 years. ${ }^{138,235,241}$ The average treatment duration until normal liver tests and normal or near-normal liver tissue is 22 months. Treatment may be extended for $\geq 3$ years, but the frequency of remission decreases to $14 \%$ and progression to cirrhosis ( $54 \%$ vs $18 \%, p=0.03$ ) and need for liver transplanta- 
tion ( $15 \%$ vs $2 \%, \mathrm{p}=0.048)$ increases compared to patients who respond fully within 12 months. ${ }^{242}$

In Europe, treatment is usually continued for at least 2 years before any decision regarding the discontinuation of therapy. ${ }^{235}$ Histological improvement commonly lags behind clinical and laboratory improvement by 3 to 8 months, and treatment should be continued beyond laboratory resolution before any attempt at drug withdrawal. ${ }^{243}$ Liver tissue examination is the preferred method of documenting histological resolution, but stable normal laboratory tests for 12 to 18 months may be sufficient to indicate the absence of histological activity and justify the termination of treatment. ${ }^{33}$

The decision to discontinue therapy must balance the possibility of a sustained long-term drug-free remission against the risk of relapse and the need for retreatment. ${ }^{244}$ The frequency of achieving a treatment-free state is $19 \%$ to $40 \%$ in studies of at least 3 years duration ${ }^{80,245-248}$ and 36\% in studies of at least 5 years duration. ${ }^{248}$ The frequency of relapse after drug withdrawal is $50 \%$ to $87 \%$ depending on duration of follow-up..$^{246,249,250}$ Relapse has been associated with progressive hepatic fibrosis in $10 \%$ and clinical deterioration in 3\%, but in most instances relapse can be effectively treated with the prompt resumption of treatment. $^{251}$

Ultimately, the decision to stop treatment must be based on patient preferences and the physician's ability to monitor for relapse and promptly restart treatment if necessary. ${ }^{244}$ Drug withdrawal can be attempted under close monitoring, and the original treatment regimen can be rapidly resumed if serum aminotransferase levels increase. A rapid and complete response to retreatment can be anticipated (Table 6). ${ }^{249}$ A long term maintenance regimen can then be instituted after normalization of liver tests by increasing the dose of azathioprine to $2 \mathrm{mg} / \mathrm{kg}$ daily and gradually withdrawing the corticosteroid. ${ }^{17,32}$

\section{Managing the suboptimal response}

Liver tests worsen during therapy (treatment failure) in 7\% of patients, ${ }^{252}$ and they improve but not to normal levels (incomplete response) in $14 \% .^{242,253}$ Treatment-ending side effects associated with corticosteroid therapy occur in $12 \%$ to $29 \%$, and they are mainly intolerable cosmetic changes, obesity, emotional instability, and vertebral compression. ${ }^{74,245,254}$ Treatment ending side effects associated with azathioprine therapy occur in 5\% to $10 \%$ of patients, and they are mainly nausea, vomiting, rash, cytopenia $(\leq 6 \%)$, pancreatitis, and liver toxicity. ${ }^{223,254,255}$ Patients with cirrhosis develop corticosteroid-induced side effects more commonly than patients without cirrhosis (25\% vs $8 \%$ ) presumably because of increased systemic levels of unbound (free) prednisolone, ${ }^{48,223}$ and they develop cytopenia that can suggest azathioprine toxicity more often (70\% vs 26\%, p<0.0001). ${ }^{239,240}$

\section{1) Treatment failure}

Patients who fail conventional treatment are treated with high doses of the original medication (Table 6). The dose of prednisone or prednisolone is increased to $30 \mathrm{mg}$ daily and the dose of azathioprine is increased to $150 \mathrm{mg}$ daily. ${ }^{18,34,39,253,256}$ Patients receiving monotherapy are treated with prednisone or prednisolone, $60 \mathrm{mg}$ daily. Treatment is continued at a fixed dose for one month. Thereafter, the doses of medication are reduced by $10 \mathrm{mg}$ of prednisone or prednisolone and $50 \mathrm{mg}$ of azathioprine after each month of laboratory and clinical improvement until conventional maintenance levels for that particular regimen are reached.

The inability to improve tests after 1 month justifies continuation of the medication in unaltered dose. Worsening of clinical or laboratory status after a dose reduction warrants an increase in the dose to the last level associated with improvement, and the regimen should be maintained for another month until an improvement warrants another attempt at dose reduction. Clinical and laboratory features improve in $70 \%$ to $100 \%$ of patients; laboratory resolution occurs in 35\%; and treatment withdrawal is possible in $20 \%$ to $35 \% .{ }^{39,257}$ Most patients remain on therapy indefinitely, and they are at risk for progression of their liver disease and the development of treatment-related side effects. Refractory progressive disease and manifestations of liver failure compel an evaluation for liver transplantation.

\section{2) Incomplete response}

Patients who have not achieved clinical, laboratory and histological normality after 36 months of conventional treatment can be classified as having an incomplete response. ${ }^{242}$ They are unlikely to achieve complete resolution with additional treatment, and the risk of drug-induced side effects increases. Management can be adjusted to prevent progression of the disease with the lowest tolerated dose of medication possible (Table 6). Therapy with prednisone or prednisolone, $10 \mathrm{mg}$ daily, in combination with azathioprine, $2 \mathrm{mg} / \mathrm{kg}$ daily, can be started, and the doses can be gradually decreased to maintain a normal or near-normal serum AST level. ${ }^{253}$ Treatment is indefinite, and the final regimen may consist of low dose corticosteroid in combination with azathioprine or monotherapy with dose-adjusted azathioprine or corticosteroid. . $^{32,258,259}$

\section{3) Drug-intolerance}

Patients with drug-intolerance are treated by decreasing the dose of the toxic medication or discontinuing its use (Table 6). ${ }^{17,253}$ The dose of the tolerated medication can be adjusted to suppress inflammatory activity. Mycophenolate mofetil (1 to 2 g daily) has been used for azathioprine intolerance, and it has successfully replaced azathioprine in 58\% of cases. . $^{41,45,46,49,50}$ Mycophenolate mofetil has side effects in $3 \%$ to $34 \%$ of patients, including cytopenia, which may resemble those of azathioprine, and it should be administered with caution or avoided in cytopenic patients. ${ }^{49,260,261}$ It also has well documented teratogenic effects that preclude its use in pregnancy. ${ }^{262-265}$ 


\section{ALTERNATIVE DRUG REGIMENS}

Budesonide, mycophenolate mofetil, and the calcineurin inhibitors (cyclosporine and tacrolimus) have been used as alternative frontline and salvage therapies in autoimmune hepatitis. ${ }^{34}$ Budesonide has emerged mainly as an alternative frontline therapy in selected patients, whereas mycophenolate mofetil and the calcineurin inhibitors have been used mainly as salvage therapies. $^{34}$

\section{Budesonide as alternative frontline therapy}

Budesonide (6 to $9 \mathrm{mg}$ daily) in combination with azathioprine (1 to $2 \mathrm{mg} / \mathrm{kg}$ daily) has been shown by randomized clinical trial to normalize serum AST and ALT levels more frequently (47\% vs $18 \%$ ) and with fewer side effects (28\% vs $53 \%$ ) than conventional combination therapy with prednisone (40 mg daily tapered to $10 \mathrm{mg}$ daily) and azathioprine (1 to $2 \mathrm{mg} / \mathrm{kg}$ daily) when administered for 6 months (Table 7). ${ }^{44}$ The histological response has not been documented; the durability of the response is unclear; and the low frequency of laboratory response $(18 \%)$ and high frequency of side effects (53\%) in the patients receiving conventional corticosteroid therapy are unexplained. Nevertheless, budesonide, a next generation glucocorticoid, in combination with azathioprine has emerged as an alternative frontline treatment for autoimmune hepatitis. ${ }^{34}$

Subset analyses of children randomized to each regimen have disclosed similar frequencies of laboratory resolution (16\% vs $15 \%$ ) and side effects (47\% vs 63\%) between the budesonide and standard regimens. ${ }^{266}$ For this reason, the superiority of budesonide therapy over standard treatment to induce remission in juvenile patients has been questioned. ${ }^{267}$ These observations indicate that budesonide therapy can have variable effects in different populations and that careful patient selection may be the key determinant of outcome.

Therapy with budesonide has been associated with the development of corticosteroid-induced complications in patients with cirrhosis, ${ }^{268,269}$ break-through exacerbations of the liver disease during treatment that have required standard therapy, ${ }^{270}$ and severe arthralgias and myalgias in patients previously treated with prednisone that have justified readministration of the standard drug regimen. ${ }^{271}$ Combination therapy with budesonide and azathioprine may be most appropriate in treatment-naïve patients with mild liver inflammation, early stage disease, and absence of concurrent immune diseases. The presence of obesity, diabetes, hypertension, or osteopenia that might be worsened by prednisone treatment also support consideration of the budesonide regimen. ${ }^{34}$

\section{Mycophenolate mofetil as frontline and salvage therapy}

Mycophenolate mofetil, a next generation purine antagonist, has been used as a frontline and salvage therapy for autoimmune hepatitis. ${ }^{34}$ As a frontline treatment in 59 patients treated for 3 to 92 months (mean, 26 months), mycophenolate mofetil ( $1 \mathrm{~g}$ daily adjusted to a final dose of 1.5 to $2 \mathrm{~g}$ daily) in combination with prednisolone $(0.5$ to $1 \mathrm{mg} / \mathrm{kg}$ daily followed by a tapered withdrawal) normalized serum ALT and $\gamma$-globulin levels in $88 \%$, induced a partial laboratory improvement in 12\%, allowed the withdrawal of corticosteroids in 58\%, and induced treatment-ending side effects in 3\% (Table 7). ${ }^{47}$ Therapy with mycophenolate mofetil and prednisolone can be effective and safe in treatment-naïve patients, but comparative clinical trials with standard therapy are necessary to establish its preference.

Mycophenolate mofetil has also been used as a salvage therapy for patients with corticosteroid-refractory liver disease or azathioprine intolerance. ${ }^{34}$ Composite analysis of the several, small, single center experiences indicates that mycophenolate

Table 7. Alternative Drug Regimens for Autoimmune Hepatitis

\begin{tabular}{|c|c|c|c|}
\hline Clinical situation & Budesonide & Mycophenolate mofetil & Calcineurin inhibitors \\
\hline \multirow[t]{3}{*}{ Treatment-naïve } & $\begin{array}{l}\text { 6-9 mg daily combined with } \\
\text { azathioprine, } 1-2 \mathrm{mg} \text { daily }^{44}\end{array}$ & $\begin{array}{l}\text { 1.5-2 g daily combined with } \\
\text { prednisolone, } 0.5-1 \mathrm{mg} / \mathrm{kg} \text { daily }^{47}\end{array}$ & $\begin{array}{l}\text { Cyclosporine, 2-5 mg/kg daily } \\
\text { (trough, } 100-300 \mathrm{ng} / \mathrm{mL})^{36}\end{array}$ \\
\hline & $\begin{array}{l}\text { Outcomes in juvenile AIH } \\
\text { equivalent to standard therapy }\end{array}$ & $\begin{array}{l}\text { No established superiority over } \\
\text { standard therapy }^{34}\end{array}$ & $\begin{array}{l}\text { Tacrolimus, } 3 \mathrm{mg} \text { twice daily } \\
\text { (serum level, } 3 \mathrm{ng} / \mathrm{mL})^{35}\end{array}$ \\
\hline & $\begin{array}{l}\text { Preferred in mild, noncirrhotic, } \\
\text { uncomplicated AIH and patients } \\
\text { with low steroid tolerance }^{34}\end{array}$ & & $\begin{array}{l}\text { Equivalent to standard combination } \\
\text { therapy and not preferred }\end{array}$ \\
\hline \multirow[t]{2}{*}{ Treatment failure } & Not effective in limited trial ${ }^{271}$ & Effective in $23 \%{ }^{34,50}$ & Cyclosporine effective in $93 \%{ }^{49}$ \\
\hline & Side effects with cirrhosis ${ }^{268,269}$ & $\begin{array}{l}\text { Avoid in pregnancy and } \\
\text { severe cytopenia }^{49,272,273}\end{array}$ & $\begin{array}{l}\text { Tacrolimus effective in } 87 \% 0^{38,276} \\
\text { Low enthusiasm despite success }{ }^{49,277}\end{array}$ \\
\hline Drug intolerance & $\begin{array}{l}\text { Difficult to switch with prednisone } \\
\text { without severe withdrawal } \\
\text { symptoms }^{271}\end{array}$ & $\begin{array}{l}\text { Effective in } 58 \%{ }^{34,50} \\
\text { Avoid in pregnancy and } \\
\text { severe cytopenia }^{49,272,273}\end{array}$ & $\begin{array}{l}\text { Limited use in steroid intolerance and } \\
\text { associated with other complexities }^{36,49}\end{array}$ \\
\hline
\end{tabular}

$\mathrm{AIH}$, autoimmune hepatitis. 
mofetil can induce improvement of laboratory tests in 45\%, facilitate the withdrawal of corticosteroids in $40 \%$, and cause treatment-ending side effects in 15\% (Table 7). ${ }^{34,50}$ Outcomes can be improved by using the treatment in a selective fashion. Therapy with mycophenolate mofetil has rescued patients who are azathioprine intolerant more commonly than patients who are refractory to conventional corticosteroid treatment (58\% vs $23 \%),{ }^{34,41,45,46,50}$ whereas children with autoimmune hepatitis and sclerosing cholangitis have not responded.

Caveats that must be considered before instituting therapy include recognition than the drug is 6 to 7 times more expensive than azathioprine, treatment is commonly indefinite, side effects develop in 3\% to 34\%, and pregnancy is an absolute contraindication to its use. .9,272,273 $^{2}$

\section{Calcineurin inhibitors as frontline and salvage therapies}

Cyclosporine has been used successfully as a frontline agent in children and adults with autoimmune hepatitis, ${ }^{36,274,275}$ but the only randomized clinical trial involving 39 patients has indicated equivalency rather than superiority of cyclosporine therapy to standard combination therapy (Table 7). ${ }^{51}$ In the absence of clear advantages that outweigh the risks of treatment (hypertension, nephrotoxicity, infection, pancreatitis, neurotoxicity and malignancy) and its expense, frontline therapy with cyclosporine cannot be justified. ${ }^{49}$ Similarly, tacrolimus (3 mg twice daily) has also had success as a frontline treatment in 21 patients who improved their serum ALT and AST levels after 3 months. ${ }^{35}$ The cytopenia and nephrotoxicity that developed in these patients were not treatment-ending, but validation of this regimen by randomized clinical trial has not emerged after 20 years.

The calcineurin inhibitors have also been used successfully to salvage patients with corticosteroid-refractory autoimmune hepatitis. ${ }^{34}$ Composite clinical experiences with cyclosporine in 22 such patients have indicated improvement of variable degree in 93\% and failure of response due to recalcitrance, drug toxicity, or noncompliance in $7 \%{ }^{49,50}$ Similarly, composite experiences with tacrolimus involving 44 patients have indicated improvement in $87 \%$ and failure of response in 13\%. ${ }^{35,38,50,276}$ The calcineurin inhibitors have been associated with serious side effects, including a paradoxical heightened state of autoreactivity, and endorsement of these agents as rescue therapies has not been universal. ${ }^{49,277}$ Furthermore, the calcineurin inhibitors have mainly immunosuppressive rather than anti-inflammatory effects, and they have not been effective in preventing autoimmune hepatitis after liver transplantation. ${ }^{113,278}$

Treatment with the calcineurin inhibitors is commonly indefinite, and it requires experience to ensure careful monitoring and appropriate dose adjustment. Cyclosporine (Neoral) has been administered in doses of 2 to $5 \mathrm{mg} / \mathrm{kg}$ body weight with dose adjustments to achieve trough levels of 100 to $300 \mathrm{ng} / \mathrm{mL},{ }^{34,36,49}$ and tacrolimus has been administered at a starting dose of 0.5 to $1 \mathrm{mg}$ daily and increased to 1 to $3 \mathrm{mg}$ twice daily as tolerated to achieve a serum level of $3 \mathrm{ng} / \mathrm{mL}$ (range, 1.7 to $10.7 \mathrm{ng}$ / $\mathrm{mL})^{34,35,38,49,276,279}$

\section{Rapamycin, rituximab, and infliximab as emerging rescue drugs}

Small clinical experiences with rapamycin (sirolimus), rituximab, and infliximab have illustrated the continuing effort that is being expended to develop rescue therapies that can supplant or supplement current corticosteroid-based regimens for autoimmune hepatitis. ${ }^{34,49,54,253}$ Rapamycin (1 to $3 \mathrm{mg}$ daily adjusted to maintain blood levels of 5 to $8 \mu \mathrm{g} / \mathrm{dL}$ ) has suppressed the inflammatory manifestations of six patients with recurrent or de novo autoimmune hepatitis after liver transplantation, including five patients who were refractory to conventional corticosteroid treatment. $^{280}$

Rituximab has improved isolated cases of autoimmune hepatitis with idiopathic thrombocytopenic purpura, ${ }^{281}$ cryoglobulinemic glomerulonephritis, ${ }^{282}$ previous B cell lymphoma, ${ }^{283}$ and Evans syndrome (hemolytic anemia and idiopathic thrombocytopenia), ${ }^{284}$ and rituximab (two infusions of $1,000 \mathrm{mg} 2$ weeks apart) has reduced serum AST levels in all six treated patients, improved histological features in four biopsied patients, and allowed corticosteroid withdrawal in three of four patients in a small treatment trial (Table 8). ${ }^{285}$

Similarly, a small trial of infliximab (infusions of $5 \mathrm{mg} / \mathrm{kg}$ body weight at time zero, 2 weeks, 6 weeks, and every 4 to 8 weeks thereafter) in 11 patients with refractory autoimmune hepatitis has normalized liver tests in eight patients, improved histological activity indices in five patients, and allowed treatment withdrawal in three patients (Table 8 ). ${ }^{55}$ The development of side effects (mainly infectious complications) in seven of the 11 patients receiving infliximab, including three patients (27\%) who required discontinuation of the drug, underscores the importance of establishing safety profiles, dosing guidelines, and monitoring strategies for each drug under trial before considering routine clinical application. ${ }^{286-291}$

\section{LIVER TRANSPLANTATION}

Liver transplantation is the ultimate rescue therapy for patients that present with features of liver failure or who develop these features during standard treatment. ${ }^{256}$ The 5- and 10year patient survivals after liver transplantation exceed $70 \%$ in adults, ${ }^{18,292-294}$ and the 5-year survival is as high as $86 \%$ in children. ${ }^{295}$ Recurrent disease can progress to cirrhosis, ${ }^{296}$ and $13 \%$ to $50 \%$ of adults with recurrent disease develop graft failure. ${ }^{15,297,298}$ Retransplantation may be necessary with the understanding that autoimmune hepatitis may still recur. ${ }^{115,296}$ Importantly, serious consequences of recurrent autoimmune hepatitis have not been uniformly experienced in all centers. The actuarial 5-year survivals for patients and grafts after re- 
Table 8. Emerging Molecular, Cellular and Pharmacological Interventions for Autoimmune Hepatitis

\begin{tabular}{|c|c|c|}
\hline Emerging interventions & Putative actions & Experience \\
\hline \multicolumn{3}{|l|}{ Molecular interventions } \\
\hline \multirow[t]{2}{*}{ CTLA-4Ig (abatacept) } & Disrupts CD28 binding to B7 ligands ${ }^{52}$ & Approved for rheumatoid arthritis ${ }^{52}$ \\
\hline & Dampens T lymphocyte activation ${ }^{34,300}$ & Improved murine model of $\mathrm{PBC}^{303}$ \\
\hline \multirow[t]{2}{*}{ Anti-CD20 (rituximab) } & Inhibits B lymphocyte activation ${ }^{53,300}$ & Isolated patients with $\mathrm{AIH}^{281-284}$ \\
\hline & & Effective in refractory $\mathrm{AIH}^{285}$ \\
\hline \multirow[t]{2}{*}{ Anti-TNF- $\alpha$ (infliximab) } & Inhibits TNF- $\alpha$ and interferes with & Effective in refractory $\mathrm{AIH}^{55}$ \\
\hline & maturation of cytotoxic $\mathrm{T}$ cells $\mathrm{s}^{34,52}$ & Frequent side effects $(27 \%)^{55}$ \\
\hline \multirow[t]{2}{*}{ Nonmitogenic anti-CD3 } & Binds to antigen receptor of $\mathrm{T}$ cells ${ }^{300}$ & Effective in diabetic model $^{307}$ \\
\hline & Promotes apoptosis of immune cells ${ }^{34,53}$ & Increases insulin in diabetic humans ${ }^{308}$ \\
\hline \multirow[t]{2}{*}{ Anti-lysyl oxidase-like 2 (simtuzumab) } & Inhibits lysyl oxidase and antifibrotic ${ }^{323}$ & Phase 2 studies to prevent fibrosis in NAFLD \\
\hline & Prevents cross-linkage of collagen ${ }^{322}$ & and PSC (https://clinicaltrials.gov) \\
\hline \multicolumn{3}{|l|}{ Cellular interventions } \\
\hline \multirow[t]{2}{*}{ Adoptive transfer of regulatory $\mathrm{T}$ cells } & Corrects deficiencies in cell population ${ }^{60}$ & Effective in models of $\mathrm{AIH}^{56,312}$ \\
\hline & Expands immune regulatory population ${ }^{60}$ & Effective in model of $\mathrm{PBC}^{313}$ \\
\hline \multirow{2}{*}{$\begin{array}{l}\text { Adoptive transfer of mesenchymal } \\
\text { stromal cells }\end{array}$} & Affects innate and adaptive immunity ${ }^{60}$ & Effective in models of $\mathrm{RA}^{301}$ \\
\hline & Inhibits B and T lymphocytes ${ }^{60}$ & Promising in early human studies ${ }^{319-321}$ \\
\hline Modulation of natural killer T cells & $\begin{array}{l}\text { Tailored glycolipid antigens skew dual } \\
\text { immune actions favorably }{ }^{59,314,315}\end{array}$ & $\begin{array}{l}\text { Effective in animal models of diabetes, RA, } \\
\text { SLE and } \mathrm{AIH}^{300,316,317}\end{array}$ \\
\hline \multicolumn{3}{|l|}{ Pharmacological prospects } \\
\hline \multirow{3}{*}{$\begin{array}{l}\text { Antioxidants (N-acetylcysteine, } \\
\text { S-adenosyl-L methionine) }\end{array}$} & Reduce reactive oxygen species ${ }^{322,323}$ & \multirow{3}{*}{$\begin{array}{l}\text { Effective in NAFLD, chronic hepatitis C, } \\
\text { and alcoholic cirrhosis } \\
\text { 324-327 }\end{array}$} \\
\hline & Decrease hepatocyte apoptosis ${ }^{322,323}$ & \\
\hline & Inhibit stellate cell activation ${ }^{322,323}$ & \\
\hline Angiotensin inhibitors (losartan) & $\begin{array}{l}\text { Reduce profibrotic transformation of hepatic } \\
\text { stellate cells to myofibroblasts }\end{array}$ & Decreased fibrosis in chronic hepatitis $\mathrm{C}^{328}$ \\
\hline
\end{tabular}

CTLA-4Ig, cytotoxic T lymphocyte antigen-4 fused with human immunoglobulin; PBC, primary biliary cholangitis; AIH, autoimmune hepatitis; TNF- $\alpha$, tumor necrosis factor-alpha; NAFLD, nonalcoholic fatty liver disease; PSC, primary sclerosing cholangitis; RA, rheumatoid arthritis; SLE, systemic lupus erythematosus.

current autoimmune hepatitis have been 100\% and $87 \%$ in one experience, ${ }^{115}$ and patient and graft survivals have been similar to those of patients transplanted for nonautoimmune liver diseases in other experiences. ${ }^{118,297,299}$ The risk of recurrent autoimmune hepatitis after liver transplantation should not affect the transplant decision. Liver transplantation is indicated by a model of end-stage liver disease (MELD) score $>16$ points, acute decompensation, intractable symptoms, treatment intolerance, or detection of liver cancer. ${ }^{293}$

\section{FUTURE DIRECTIONS}

Most new therapeutic interventions have not moved beyond the theoretical stage in autoimmune hepatitis, but their premise and promise are founded on studies already performed in cell cultures, animal models, or preliminary clinical trials in other immune-mediated diseases..$^{34,52,53,300,301}$ They await rigorous study in autoimmune hepatitis.

\section{Feasible molecular interventions}

Monoclonal antibodies to tumor necrosis factor- $\alpha$ (infliximab) $^{55}$ and monoclonal antibodies to CD20 (rituximab) ${ }^{285}$ have already begun an evaluation process in the treatment of autoimmune hepatitis (Table 8). Other molecular interventions that have advanced in animal studies and clinical trials outside autoimmune hepatitis also warrant consideration in this disease. Molecular interventions are intended to blunt or correct detrimental pathological mechanisms, but they may also interfere with normal homeostatic mechanisms and have unintended consequences. Their introduction as therapeutic agents requires an awareness of these possible consequences and rigorous evaluation in clinical trials.

Cytotoxic T lymphocyte antigen-4 fused with immunoglobulin (CTLA-4Ig) is a dimeric recombinant human fusion protein that is a homologue of the CD28 molecule expressed on the surface of $\mathrm{CD}^{+} \mathrm{T}$ lymphocytes (Table 8$)^{52}$ CTLA-4Ig can interfere with the binding of CD28 with the B7 ligands (CD80 and CD86) expressed on antigen-presenting cells and prevent completion 
of the signaling pathway necessary for lymphocyte activation. ${ }^{302}$ CTLA-4Ig is already approved for use in rheumatoid arthritis, and it has improved the serological and histological manifestations of PBC in a murine model. ${ }^{303}$

Nonmitogenic monoclonal antibodies to CD3 target the T cell antigen receptor of $\mathrm{T}$ lymphocytes, and they can promote the apoptosis of immune cells (Table 8). ${ }^{300,304}$ The newly released apoptotic bodies can then be ingested by macrophages and dendritic cells, and these cells can in turn produce transforming growth factor $\beta$ (TGF- $\beta$ ). ${ }^{305}$ Regulatory $\mathrm{T}$ cells that express the latency-associated peptide can be induced by TGF- $\beta$ and expand the immunosuppressive effect. ${ }^{306}$ Antibodies to CD3 have already been shown to induce complete and durable remission in nonobese diabetic mice, ${ }^{307}$ and clinical trials have demonstrated its effectiveness in maintaining or increasing insulin production in patients with insulin-dependent autoimmune diabetes. $^{308}$

Simtuzumab (GS-6624) is a monoclonal antibody that is directed against the enzyme that promotes the cross-linkage of collagen fibrils and expansion of extracellular matrix (Table 8). Simtuzumab has been safe and well-tolerated in Phase 1 studies involving patients with hepatic fibrosis, and this monoclonal antibody to lysyl oxidase-like 2 has entered Phase 2 clinical studies designed to prevent hepatic fibrosis in NAFLD and PSC (https://clinicaltrials.gov., NCT01672853 and NCT016772879). The results of these trials will direct future applications of this preparation.

\section{Feasible cellular interventions}

Regulatory $\mathrm{T}$ cells and natural killer $\mathrm{T}$ cells are cell populations that help modulate immune reactivity, and they have been manipulated to suppress inflammatory and immune responses in animal models of diverse immune-mediated diseases (Table 8). ${ }^{59,300}$ Regulatory $\mathrm{T}$ cells can be expanded by pharmacological agents (corticosteroids, rapamycin, mycophenolate mofetil, and 1,25 dihydroxyvitamin D3 $)^{59}$ or by the adoptive transfer of autologous cells that have been expanded or newly generated ex vivo and reintroduced. ${ }^{60}$ Deficiencies in the number and function of regulatory $\mathrm{T}$ cells have been reported in autoimmune hepatitis, ${ }^{309,310}$ albeit these findings have not been confirmed. ${ }^{311}$ Despite the uncertainties, the adoptive transfer of regulatory $\mathrm{T}$ cells has been effective in a thymectomized neonatal mouse model of autoimmune hepatitis ${ }^{312}$ and a murine model of autoimmune hepatitis based on immunization with the human antigens, formiminotransferase cyclodeaminase and cytochrome P450 D2. ${ }^{56}$ Furthermore, adoptive transfer of these cells in a murine model of autoimmune cholangitis has reduced portal inflammation, bile duct damage, and the inflammatory response. ${ }^{313}$ These experimental observations support the continued study of regulatory $\mathrm{T}$ cell expansion in the management of autoimmune hepatitis.

Natural killer $\mathrm{T}$ cells have stimulatory and inhibitory actions on the innate and adaptive immune responses, and they are amenable to manipulation by antigenic stimuli that promote the desired predominant action (Table 8)..$^{59,300,314}$ Natural killer T cells expressing a semi-invariant antigen receptor recognize glycolipid antigens bound to the CD1 antigen-presenting molecule, and glycolipid antigens can be designed to elicit the preferred action of these cells. ${ }^{315}$ Natural killer T cells have been evaluated in animal models of type 1 diabetes, systemic lupus erythematosus, rheumatoid arthritis, and autoimmune encephalomyelitis, ${ }^{300}$ and studies in experimental autoimmune hepatitis have supported the further investigation of their pathogenic role and therapeutic implications in this disease. ${ }^{316,317}$

Mesenchymal stromal cells also affect the innate and adaptive immune responses by modulating the activity of macrophages, natural killer cells, and dendritic cells and by inhibiting the activity of $\mathrm{B}$ and $\mathrm{T}$ lymphocytes (Table 8$){ }^{60}$ The adoptive transfer of mesenchymal stromal cells has been effective in murine models of rheumatoid arthritis and radiation-induced liver injury, ${ }^{301,318}$ and its therapeutic promise has been supported by preliminary human experiences in refractory Crohn's disease, corticosteroid-resistant graft-versus-host disease, and allograft rejection after kidney transplantation. ${ }^{319-321}$ Serious side effects have not been encountered in mid-term human studies, but questions remain regarding the preferred expansion technique, the rare occurrence of immunogenicity in animal models, and the possible induction of chromosome aberrations, transient aneuploidy, or malignant transformations in cell cultures from murine and human sources. ${ }^{60}$ There have been no reported experiences in autoimmune hepatitis. ${ }^{320}$

\section{Pharmacological prospects}

The generation of reactive oxygen species from Kupffer cells and myofibroblasts promotes the apoptosis of hepatocytes, the release of apoptotic bodies, and the activation of hepatic stellate cells. ${ }^{322,323}$ Antioxidants (N-acetylcysteine, S-adenosyl-Lmethionine, and vitamin E) have already been shown in clinical experiences to decrease histological activity, TGF- $\beta$ production, and fibrosis in NAFLD (Table 8). ${ }^{34,325}$ They have also improved mortality in alcoholic cirrhosis, ${ }^{326}$ and enhanced early viral responses in chronic hepatitis C. ${ }^{327}$ Angiotensin inhibitors may inhibit the transformation of hepatic stellate cells into myofibroblasts, and losartan has decreased fibrosis in chronic hepatitis C. ${ }^{328}$ The antioxidants and the angiotensin inhibitors are feasible antiapoptotic and antifibrotic agents that warrant evaluation as adjunctive therapies in autoimmune hepatitis. ${ }^{329-332}$

Agents that reduce apoptosis are feasible interventions in autoimmune hepatitis if their actions can be directed to the pertinent cell population. Caspase inhibitors have reduced apoptosis in murine models of acute liver injury, ${ }^{333}$ bile duct ligation, ${ }^{334}$ NAFLD, ${ }^{335}$ and acute liver failure after massive hepatectomy. ${ }^{336}$ They have also been used in limited clinical experiences involving patients with chronic hepatitis $\mathrm{C}^{337,338}$ and NAFLD ${ }^{337}$ and in 
organs for liver transplantation to protect against ischemia/reperfusion injury. ${ }^{339}$ The major concern is the possibility of unintended interference with normal apoptotic pathways that guard against the invasion of pathogens and the malignant transformation of cells. ${ }^{57}$ Caspase inhibitors have not been evaluated in autoimmune hepatitis.

Patients with chronic liver disease, including autoimmune hepatitis, have reduced serum levels of 25-hydroxyvitamin D, and this deficiency has been associated with disease severity and hepatic fibrosis. ${ }^{340-345}$ Vitamin D protects against oxidative stress, limits the proliferation of myofibroblasts, stimulates the expansion of regulatory $\mathrm{T}$ cells, reduces the production of proinflammatory cytokines, and modulates activation of immune effector cells. ${ }^{346-348}$ Low serum levels of 25-hydroxyvitamin D may compromise these diverse beneficial actions, and vitamin D supplementation may be a measure to bolster actions that protect hepatocytes. ${ }^{349}$ The impact of supplemental vitamin D therapy on the severity and responsiveness of corticosteroidtreated autoimmune hepatitis also requires evaluation.

\section{CONFLICTS OF INTEREST}

No potential conflict of interest relevant to this article was reported.

\section{REFERENCES}

1. Czaja AJ. Diverse manifestations and evolving treatments of autoimmune hepatitis. Minerva Gastroenterol Dietol 2005;51:313333.

2. Czaja AJ. Special clinical challenges in autoimmune hepatitis: the elderly, males, pregnancy, mild disease, fulminant onset, and nonwhite patients. Semin Liver Dis 2009;29:315-330.

3. Czaja AJ, Bayraktar Y. Non-classical phenotypes of autoimmune hepatitis and advances in diagnosis and treatment. World J Gastroenterol 2009;15:2314-2328.

4. Czaja AJ. Autoimmune hepatitis in special patient populations. Best Pract Res Clin Gastroenterol 2011;25:689-700.

5. Czaja AJ. Autoimmune hepatitis in diverse ethnic populations and geographical regions. Expert Rev Gastroenterol Hepatol 2013;7:365-385.

6. Cowling DC, Mackay IR, Taft LI. Lupoid hepatitis. Lancet 1956; 271:1323-1326.

7. Read AE, Sherlock S, Harrison CV. Active 'juvenile' cirrhosis considered as part of a systemic disease and the effect of corticosteroid therapy. Gut 1963;4:378-393.

8. Mackay IR. Auto-immune (lupoid) hepatitis: an entity in the spectrum of chronic active liver disease. J Gastroenterol Hepatol 1990;5:352-359.

9. Czaja AJ, Donaldson PT. Gender effects and synergisms with histocompatibility leukocyte antigens in type 1 autoimmune hepatitis. Am J Gastroenterol 2002;97:2051-2057.
10. Al-Chalabi T, Underhill JA, Portmann BC, McFarlane IG, Heneghan MA. Impact of gender on the long-term outcome and survival of patients with autoimmune hepatitis. J Hepatol 2008; 48:140-147.

11. Gregorio GV, Portmann B, Reid F, et al. Autoimmune hepatitis in childhood: a 20-year experience. Hepatology 1997;25:541-547.

12. Czaja AJ, Souto EO, Bittencourt PL, et al. Clinical distinctions and pathogenic implications of type 1 autoimmune hepatitis in Brazil and the United States. J Hepatol 2002;37:302-308.

13. Al-Chalabi T, Boccato S, Portmann BC, McFarlane IG, Heneghan MA. Autoimmune hepatitis (AIH) in the elderly: a systematic retrospective analysis of a large group of consecutive patients with definite $\mathrm{AIH}$ followed at a tertiary referral centre. J Hepatol 2006;45:575-583.

14. Czaja AJ, Carpenter HA. Distinctive clinical phenotype and treatment outcome of type 1 autoimmune hepatitis in the elderly. Hepatology 2006;43:532-538.

15. Zolfino T, Heneghan MA, Norris S, Harrison PM, Portmann BC, McFarlane IG. Characteristics of autoimmune hepatitis in patients who are not of European Caucasoid ethnic origin. Gut 2002;50: 713-717.

16. Czaja AJ. Autoimmune hepatitis. Part B: diagnosis. Expert Rev Gastroenterol Hepatol 2007;1:129-143.

17. Manns MP, Czaja AJ, Gorham JD, et al. Diagnosis and management of autoimmune hepatitis. Hepatology 2010;51:2193-2213.

18. Czaja AJ. Diagnosis and management of autoimmune hepatitis. Clin Liver Dis 2015;19:57-79.

19. Alvarez F, Berg PA, Bianchi FB, et al. International Autoimmune Hepatitis Group Report: review of criteria for diagnosis of autoimmune hepatitis. J Hepatol 1999;31:929-938.

20. Hennes EM, Zeniya M, Czaja AJ, et al. Simplified criteria for the diagnosis of autoimmune hepatitis. Hepatology 2008;48:169-176.

21. Czaja AJ. Performance parameters of the diagnostic scoring systems for autoimmune hepatitis. Hepatology 2008;48:1540-1548.

22. Manns M, Gerken G, Kyriatsoulis A, Staritz M, Meyer zum Büschenfelde KH. Characterisation of a new subgroup of autoimmune chronic active hepatitis by autoantibodies against a soluble liver antigen. Lancet 1987;1:292-294.

23. Costa M, Rodríguez-Sánchez JL, Czaja AJ, Gelpí C. Isolation and characterization of cDNA encoding the antigenic protein of the human tRNP(Ser)Sec complex recognized by autoantibodies from patients withtype-1 autoimmune hepatitis. Clin Exp Immunol 2000;121:364-374.

24. Czaja AJ, Donaldson PT, Lohse AW. Antibodies to soluble liver antigen/liver pancreas and HLA risk factors for type 1 autoimmune hepatitis. Am J Gastroenterol 2002;97:413-419.

25. Ma Y, Okamoto M, Thomas MG, et al. Antibodies to conformational epitopes of soluble liver antigen define a severe form of autoimmune liver disease. Hepatology 2002;35:658-664.

26. Baeres M, Herkel J, Czaja AJ, et al. Establishment of standardised SLA/LP immunoassays: specificity for autoimmune hepatitis, worldwide occurrence, and clinical characteristics. Gut 
2002;51:259-264.

27. Guéguen P, Dalekos G, Nousbaum JB, et al. Double reactivity against actin and alpha-actinin defines a severe form of autoimmune hepatitis type 1. J Clin Immunol 2006;26:495-505.

28. Czaja AJ. Autoantibodies as prognostic markers in autoimmune liver disease. Dig Dis Sci 2010;55:2144-2161.

29. Oikonomou KG, Zachou K, Dalekos GN. Alpha-actinin: a multidisciplinary protein with important role in B-cell driven autoimmunity. Autoimmun Rev 2011;10:389-396.

30. Zachou K, Oikonomou K, Renaudineau Y, et al. Anti-alpha actinin antibodies as new predictors of response to treatment in autoimmune hepatitis type 1. Aliment Pharmacol Ther 2012;35:116-125.

31. Montano-Loza AJ, Shums Z, Norman GL, Czaja AJ. Prognostic implications of antibodies to Ro/SSA and soluble liver antigen in type 1 autoimmune hepatitis. Liver Int 2012;32:85-92.

32. Johnson PJ, McFarlane IG, Williams R. Azathioprine for longterm maintenance of remission in autoimmune hepatitis. N Engl J Med 1995;333:958-963.

33. Gleeson D, Heneghan MA; British Society of Gastroenterology. British Society of Gastroenterology (BSG) guidelines for management of autoimmune hepatitis. Gut 2011;60:1611-1629.

34. Czaja AJ. Current and prospective pharmacotherapy for autoimmune hepatitis. Expert Opin Pharmacother 2014;15:1715-1736.

35. Van Thiel DH, Wright H, Carroll P, et al. Tacrolimus: a potential new treatment for autoimmune chronic active hepatitis: results of an open-label preliminary trial. Am J Gastroenterol 1995;90:771776.

36. Malekzadeh R, Nasseri-Moghaddam S, Kaviani MJ, Taheri H, Kamalian N, Sotoudeh M. Cyclosporin A is a promising alternative to corticosteroids in autoimmune hepatitis. Dig Dis Sci 2001;46: 1321-1327.

37. Devlin SM, Swain MG, Urbanski SJ, Burak KW. Mycophenolate mofetil for the treatment of autoimmune hepatitis in patients refractory to standard therapy. Can J Gastroenterol 2004;18:321-326.

38. Aqel BA, Machicao V, Rosser B, Satyanarayana R, Harnois DM, Dickson RC. Efficacy of tacrolimus in the treatment of steroid refractory autoimmune hepatitis. J Clin Gastroenterol 2004;38:805809.

39. Czaja AJ, Carpenter HA. Empiric therapy of autoimmune hepatitis with mycophenolate mofetil: comparison with conventional treatment for refractory disease. J Clin Gastroenterol 2005;39:819-825.

40. Inductivo-Yu I, Adams A, Gish RG, et al. Mycophenolate mofetil in autoimmune hepatitis patients not responsive or intolerant to standard immunosuppressive therapy. Clin Gastroenterol Hepatol 2007;5:799-802.

41. Hennes EM, Oo YH, Schramm C, et al. Mycophenolate mofetil as second line therapy in autoimmune hepatitis? Mycophenolate mofetil in autoimmune hepatitis. Am J Gastroenterol 2008;103: 3063-3070

42. Hlivko JT, Shiffman ML, Stravitz RT, et al. A single center review of the use of mycophenolate mofetil in the treatment of autoimmune hepatitis. Clin Gastroenterol Hepatol 2008;6:1036-1040.
43. Wolf DC, Bojito L, Facciuto M, Lebovics E. Mycophenolate mofetil for autoimmune hepatitis: a single practice experience. Dig Dis Sci 2009;54:2519-2522.

44. Manns MP, Woynarowski M, Kreisel W, et al. Budesonide induces remission more effectively than prednisone in a controlled trial of patients with autoimmune hepatitis. Gastroenterology 2010;139:1198-1206.

45. Sharzehi K, Huang MA, Schreibman IR, Brown KA. Mycophenolate mofetil for the treatment of autoimmune hepatitis in patients refractory or intolerant to conventional therapy. Can J Gastroenterol 2010;24:588-592.

46. Baven-Pronk AM, Coenraad MJ, van Buuren HR, et al. The role of mycophenolate mofetil in the management of autoimmune hepatitis and overlap syndromes. Aliment Pharmacol Ther 2011;34:335-343.

47. Zachou K, Gatselis N, Papadamou G, Rigopoulou EI, Dalekos GN. Mycophenolate for the treatment of autoimmune hepatitis: prospective assessment of its efficacy and safety for induction and maintenance of remission in a large cohort of treatment-naive patients. J Hepatol 2011;55:636-646.

48. Czaja AJ. Drug choices in autoimmune hepatitis. Part A: steroids. Expert Rev Gastroenterol Hepatol 2012;6:603-615.

49. Czaja AJ. Drug choices in autoimmune hepatitis. Part B: nonsteroids. Expert Rev Gastroenterol Hepatol 2012;6:617-635.

50. Czaja AJ. Autoimmune hepatitis: focusing on treatments other than steroids. Can J Gastroenterol 2012;26:615-620.

51. Nasseri-Moghaddam S, Nikfam S, Karimian S, Khashayar P, Malekzadeh R. Cyclosporine-A versus prednisolone for induction of remission in auto-immune hepatitis: interim analysis report of a randomized controlled trial. Middle East J Dig Dis 2013;5:193-200.

52. Czaja AJ. Emerging opportunities for site-specific molecular and cellular interventions in autoimmune hepatitis. Dig Dis Sci 2010;55:2712-2726.

53. Czaja AJ. Promising pharmacological, molecular and cellular treatments of autoimmune hepatitis. Curr Pharm Des 2011;17: 3120-3140.

54. Czaja AJ. Nonstandard drugs and feasible new interventions for autoimmune hepatitis. Part I. Inflamm Allergy Drug Targets 2012;11:337-350

55. Weiler-Normann C, Schramm C, Quaas A, et al. Infliximab as a rescue treatment in difficult-to-treat autoimmune hepatitis. $\mathrm{J}$ Hepatol 2013;58:529-534.

56. Lapierre P, Béland K, Yang R, Alvarez F. Adoptive transfer of ex vivo expanded regulatory $\mathrm{T}$ cells in an autoimmune hepatitis murine model restores peripheral tolerance. Hepatology 2013;57:217-227.

57. Czaja AJ. Targeting apoptosis in autoimmune hepatitis. Dig Dis Sci 2014;59:2890-2904.

58. Czaja AJ. Review article: chemokines as orchestrators of autoimmune hepatitis and potential therapeutic targets. Aliment Pharmacol Ther 2014;40:261-279.

59. Montano-Loza AJ, Czaja AJ. Cell mediators of autoimmune hepa- 
titis and their therapeutic implications. Dig Dis Sci 2015;60:15281542.

60. Czaja AJ. Adoptive cell transfer in autoimmune hepatitis. Expert Rev Gastroenterol Hepatol 2015;9:821-836.

61. Czaja AJ. Acute and acute severe (fulminant) autoimmune hepatitis. Dig Dis Sci 2013;58:897-914.

62. Crapper RM, Bhathal PS, Mackay IR, Frazer IH. 'Acute' autoimmune hepatitis. Digestion 1986;34:216-225.

63. Nikias GA, Batts KP, Czaja AJ. The nature and prognostic implications of autoimmune hepatitis with an acute presentation. $\mathrm{J}$ Hepatol 1994;21:866-871.

64. Michalska Z, Radowska D, Staike P, et al. Autoimmune hepatitis in the material of Department and Regional Hospital of Infectious Diseases in Gdańsk. Med Sci Monit 2003;9 Suppl 3:49-54.

65. Ferrari R, Pappas G, Agostinelli D, et al. Type 1 autoimmune hepatitis: patterns of clinical presentation and differential diagnosis of the 'acute' type. QJM 2004;97:407-412.

66. Lee WS, McKiernan P, Kelly DA. Etiology, outcome and prognostic indicators of childhood fulminant hepatic failure in the United kingdom. J Pediatr Gastroenterol Nutr 2005;40:575-581.

67. Stravitz RT, Lefkowitch JH, Fontana RJ, et al. Autoimmune acute liver failure: proposed clinical and histological criteria. Hepatology 2011;53:517-526.

68. Yasui S, Fujiwara K, Yonemitsu Y, Oda S, Nakano M, Yokosuka 0. Clinicopathological features of severe and fulminant forms of autoimmune hepatitis. J Gastroenterol 2011;46:378-390.

69. Fujiwara K, Fukuda Y, Yokosuka O. Precise histological evaluation of liver biopsy specimen is indispensable for diagnosis and treatment of acute-onset autoimmune hepatitis. J Gastroenterol 2008:43:951-958

70. Czaja AJ. Reply: acute and acute severe (fulminant) autoimmune hepatitis. Dig Dis Sci 2013;58:1809-1810.

71. Yasui S, Fujiwara K, Okitsu K, Yonemitsu Y, Ito H, Yokosuka O. Importance of computed tomography imaging features for the diagnosis of autoimmune acute liver failure. Hepatol Res 2012;42:42-50.

72. Feld JJ, Dinh H, Arenovich T, Marcus VA, Wanless IR, Heathcote EJ. Autoimmune hepatitis: effect of symptoms and cirrhosis on natural history and outcome. Hepatology 2005;42:53-62.

73. Kogan J, Safadi R, Ashur Y, Shouval D, Ilan Y. Prognosis of symptomatic versus asymptomatic autoimmune hepatitis: a study of 68 patients. J Clin Gastroenterol 2002;35:75-81.

74. Czaja AJ. Features and consequences of untreated type 1 autoimmune hepatitis. Liver Int 2009;29:816-823.

75. Czaja AJ. Autoantibody-negative autoimmune hepatitis. Dig Dis Sci 2012;57:610-624.

76. Czaja AJ. Cryptogenic chronic hepatitis and its changing guise in adults. Dig Dis Sci 2011;56:3421-3438.

77. Czaja AJ, Carpenter HA, Santrach PJ, Moore SB, Homburger HA. The nature and prognosis of severe cryptogenic chronic active hepatitis. Gastroenterology 1993;104:1755-1761.

78. Heringlake S, Schütte A, Flemming P, Schmiegel W, Manns MP,
Tillmann HL. Presumed cryptogenic liver disease in Germany: high prevalence of autoantibody-negative autoimmune hepatitis, low prevalence of NASH, no evidence for occult viral etiology. Z Gastroenterol 2009;47:417-423.

79. Mehendiratta V, Mitroo P, Bombonati A, et al. Serologic markers do not predict histologic severity or response to treatment in patients with autoimmune hepatitis. Clin Gastroenterol Hepatol 2009;7:98-103.

80. Seo S, Toutounjian R, Conrad A, Blatt L, Tong MJ. Favorable outcomes of autoimmune hepatitis in a community clinic setting. J Gastroenterol Hepatol 2008;23:1410-1414.

81. Gassert DJ, Garcia H, Tanaka K, Reinus JF. Corticosteroid-responsive cryptogenic chronic hepatitis: evidence for seronegative autoimmune hepatitis. Dig Dis Sci 2007;52:2433-2437.

82. Miyake Y, Yamamoto K. Current status of autoimmune hepatitis in Japan. Acta Med Okayama 2008;62:217-226.

83. Bernal W, Ma Y, Smith HM, Portmann B, Wendon J, Vergani D. The significance of autoantibodies and immunoglobulins in acute liver failure: a cohort study. J Hepatol 2007;47:664-670.

84. Hiramatsu A, Takahashi S, Aikata H, et al. Etiology and outcome of acute liver failure: retrospective analysis of 50 patients treated at a single center. J Gastroenterol Hepatol 2008;23(8 Pt 1):12161222.

85. McFarlane IG. Pathogenesis of autoimmune hepatitis. Biomed Pharmacother 1999;53:255-263.

86. Czaja AJ. Behavior and significance of autoantibodies in type 1 autoimmune hepatitis. J Hepatol 1999;30:394-401.

87. Kanzler S, Weidemann C, Gerken G, et al. Clinical significance of autoantibodies to soluble liver antigen in autoimmune hepatitis. J Hepatol 1999;31:635-640.

88. Targan SR, Landers C, Vidrich A, Czaja AJ. High-titer antineutrophil cytoplasmic antibodies in type-1 autoimmune hepatitis. Gastroenterology 1995;108:1159-1166.

89. Kaukinen K, Halme L, Collin P, et al. Celiac disease in patients with severe liver disease: gluten-free diet may reverse hepatic failure. Gastroenterology 2002;122:881-888.

90. Abdo A, Meddings J, Swain M. Liver abnormalities in celiac disease. Clin Gastroenterol Hepatol 2004;2:107-112.

91. Rubio-Tapia A, Murray JA. Liver involvement in celiac disease. Minerva Med 2008;99:595-604

92. Volta U. Pathogenesis and clinical significance of liver injury in celiac disease. Clin Rev Allergy Immunol 2009;36:62-70.

93. Prasad KK, Debi U, Sinha SK, Nain CK, Singh K. Hepatobiliary disorders in celiac disease: an update. Int J Hepatol 2011;2011:438184.

94. Miyake Y, Iwasaki Y, Terada R, et al. Clinical features of Japanese type 1 autoimmune hepatitis patients with zone III necrosis. Hepatol Res 2007;37:801-805.

95. Okano N, Yamamoto K, Sakaguchi K, et al. Clinicopathological features of acute-onset autoimmune hepatitis. Hepatol Res 2003;25:263-270.

96. Kessler WR, Cummings OW, Eckert G, Chalasani N, Lumeng 
L, Kwo PY. Fulminant hepatic failure as the initial presentation of acute autoimmune hepatitis. Clin Gastroenterol Hepatol 2004;2:625-631.

97. Singh R, Nair S, Farr G, Mason A, Perrillo R. Acute autoimmune hepatitis presenting with centrizonal liver disease: case report and review of the literature. Am J Gastroenterol 2002;97:2670-2673.

98. Ludwig J, Czaja AJ, Dickson ER, LaRusso NF, Wiesner RH. Manifestations of nonsuppurative cholangitis in chronic hepatobiliary diseases: morphologic spectrum, clinical correlations and terminology. Liver 1984;4:105-116.

99. Czaja AJ, Carpenter HA, Santrach PJ, Moore SB. Autoimmune cholangitis within the spectrum of autoimmune liver disease. Hepatology 2000;31:1231-1238.

100. Czaja AJ, Carpenter HA. Autoimmune hepatitis with incidental histologic features of bile duct injury. Hepatology 2001;34(4 Pt 1): 659-665.

101. Czaja AJ, Muratori P, Muratori L, Carpenter HA, Bianchi FB. Diagnostic and therapeutic implications of bile duct injury in autoimmune hepatitis. Liver Int 2004;24:322-329.

102. Czaja AJ. Cholestatic phenotypes of autoimmune hepatitis. Clin Gastroenterol Hepatol 2014;12:1430-1438.

103. Kim WR, Ludwig J, Lindor KD. Variant forms of cholestatic diseases involving small bile ducts in adults. Am J Gastroenterol 2000;95:1130-1138.

104. Angulo P, Maor-Kendler Y, Lindor KD. Small-duct primary sclerosing cholangitis: a long-term follow-up study. Hepatology 2002;35:1494-1500.

105. Chazouillères O, Wendum D, Serfaty L, Montembault S, Rosmorduc 0, Poupon R. Primary biliary cirrhosis-autoimmune hepatitis overlap syndrome: clinical features and response to therapy. Hepatology 1998;28:296-301.

106. Czaja AJ. Frequency and nature of the variant syndromes of autoimmune liver disease. Hepatology 1998;28:360-365.

107. Czaja AJ. The overlap syndromes of autoimmune hepatitis. Dig Dis Sci 2013;58:326-343.

108. Kerkar N, Hadzić N, Davies ET, et al. De-novo autoimmune hepatitis after liver transplantation. Lancet 1998;351:409-413.

109. Heneghan MA, Portmann BC, Norris SM, et al. Graft dysfunction mimicking autoimmune hepatitis following liver transplantation in adults. Hepatology 2001;34:464-470.

110. González-Koch A, Czaja AJ, Carpenter HA, et al. Recurrent autoimmune hepatitis after orthotopic liver transplantation. Liver Transpl 2001;7:302-310.

111. Czaja AJ. Autoimmune hepatitis after liver transplantation and other lessons of self-intolerance. Liver Transpl 2002;8:505-513.

112. Czaja AJ. Recurrent autoimmune hepatitis after liver transplantation: a disease continuum or a fresh start? Liver Transpl 2009;15:1169-1171.

113. Czaja AJ. Diagnosis, pathogenesis, and treatment of autoimmune hepatitis after liver transplantation. Dig Dis Sci 2012;57:22482266.

114. Neuberger J, Portmann B, Calne R, Williams R. Recurrence of autoimmune chronic active hepatitis following orthotopic liver grafting. Transplantation 1984;37:363-365.

115. Ratziu V, Samuel D, Sebagh M, et al. Long-term follow-up after liver transplantation for autoimmune hepatitis: evidence of recurrence of primary disease. J Hepatol 1999;30:131-141.

116. Molmenti EP, Netto GJ, Murray NG, et al. Incidence and recurrence of autoimmune/alloimmune hepatitis in liver transplant recipients. Liver Transpl 2002;8:519-526.

117. Duclos-Vallée JC, Sebagh M, Rifai K, et al. A 10 year follow up study of patients transplanted for autoimmune hepatitis: histological recurrence precedes clinical and biochemical recurrence. Gut 2003;52:893-897.

118. Vogel A, Heinrich E, Bahr MJ, et al. Long-term outcome of liver transplantation for autoimmune hepatitis. Clin Transplant 2004;18:62-69.

119. Prados E, Cuervas-Mons V, de la Mata M, et al. Outcome of autoimmune hepatitis after liver transplantation. Transplantation 1998;66:1645-1650.

120. Hernandez HM, Kovarik P, Whitington PF, Alonso EM. Autoimmune hepatitis as a late complication of liver transplantation. $\mathrm{J}$ Pediatr Gastroenterol Nutr 2001;32:131-136.

121. Montano-Loza AJ, Mason AL, Ma M, Bastiampillai RJ, Bain VG, Tandon P. Risk factors for recurrence of autoimmune hepatitis after liver transplantation. Liver Transpl 2009;15:1254-1261.

122. Campsen J, Zimmerman MA, Trotter JF, et al. Liver transplantation for autoimmune hepatitis and the success of aggressive corticosteroid withdrawal. Liver Transpl 2008;14:1281-1286.

123. Gupta P, Hart J, Millis JM, Cronin D, Brady L. De novo hepatitis with autoimmune antibodies and atypical histology: a rare cause of late graft dysfunction after pediatric liver transplantation. Transplantation 2001;71:664-668.

124. Aguilera I, Wichmann I, Sousa JM, et al. Antibodies against glutathione S-transferase T1 (GSTT1) in patients with de novo immune hepatitis following liver transplantation. Clin Exp Immunol 2001;126:535-539.

125. Cho JM, Kim KM, Oh SH, Lee YJ, Rhee KW, Yu E. De novo autoimmune hepatitis in Korean children after liver transplantation: a single institution's experience. Transplant Proc 2011;43:23942396.

126. Andries S, Casamayou L, Sempoux C, et al. Posttransplant immune hepatitis in pediatric liver transplant recipients: incidence and maintenance therapy with azathioprine. Transplantation 2001;72:267-272.

127. Duclos-Vallée JC. Recurrence of autoimmune hepatitis, primary biliary cirrhosis and primary sclerosing cholangitis after liver transplantation. Acta Gastroenterol Belg 2005;68:331-336.

128. Aguilera I, Sousa JM, Gavilán F, Bernardos A, Wichmann I, Nuñez-Roldán A. Glutathione S-transferase T1 mismatch constitutes a risk factor for de novo immune hepatitis after liver transplantation. Liver Transpl 2004;10:1166-1172.

129. Czaja AJ. The variant forms of autoimmune hepatitis. Ann Intern Med 1996;125:588-598. 
130. Boberg KM, Chapman RW, Hirschfield GM, et al. Overlap syndromes: the International Autoimmune Hepatitis Group (IAIHG) position statement on a controversial issue. J Hepatol 2011;54: 374-385.

131. Chapman R, Fevery J, Kalloo A, et al. Diagnosis and management of primary sclerosing cholangitis. Hepatology 2010;51:660-678.

132. Lindor KD, Gershwin ME, Poupon R, et al. Primary biliary cirrhosis. Hepatology 2009;50:291-308.

133. Papamichalis PA, Zachou K, Koukoulis GK, et al. The revised international autoimmune hepatitis score in chronic liver diseases including autoimmune hepatitis/overlap syndromes and autoimmune hepatitis with concurrent other liver disorders. J Autoimmune Dis 2007;4:3.

134. Gatselis NK, Zachou K, Papamichalis P, et al. Comparison of simplified score with the revised original score for the diagnosis of autoimmune hepatitis: a new or a complementary diagnostic score? Dig Liver Dis 2010;42:807-812.

135. Kuiper EM, Zondervan PE, van Buuren HR. Paris criteria are effective in diagnosis of primary biliary cirrhosis and autoimmune hepatitis overlap syndrome. Clin Gastroenterol Hepatol 2010;8:530-534.

136. Rockey DC, Caldwell SH, Goodman ZD, Nelson RC, Smith AD; American Association for the Study of Liver Diseases. Liver biopsy. Hepatology 2009;49:1017-1044.

137. Björnsson E, Talwalkar J, Treeprasertsuk S, Neuhauser M, Lindor K. Patients with typical laboratory features of autoimmune hepatitis rarely need a liver biopsy for diagnosis. Clin Gastroenterol Hepatol 2011;9:57-63.

138. Czaja AJ. Review article: the management of autoimmune hepatitis beyond consensus guidelines. Aliment Pharmacol Ther 2013;38:343-364.

139. Johnson PJ, McFarlane IG. Meeting report: International Autoimmune Hepatitis Group. Hepatology 1993;18:998-1005.

140. Czaja A, Carpenter HA. Validation of scoring system for diagnosis of autoimmune hepatitis. Dig Dis Sci 1996;41:305-314.

141. Yeoman AD, Westbrook RH, Al-Chalabi T, et al. Diagnostic value and utility of the simplified International Autoimmune Hepatitis Group (IAIHG) criteria in acute and chronic liver disease. Hepatology 2009;50:538-545.

142. Boberg KM, Fausa 0, Haaland T, et al. Features of autoimmune hepatitis in primary sclerosing cholangitis: an evaluation of 114 primary sclerosing cholangitis patients according to a scoring system for the diagnosis of autoimmune hepatitis. Hepatology 1996;23:1369-1376.

143. Czaja AJ. Comparability of probable and definite autoimmune hepatitis by international diagnostic scoring criteria. Gastroenterology 2011;140:1472-1480.

144. Talwalkar JA, Keach JC, Angulo P, Lindor KD. Overlap of autoimmune hepatitis and primary biliary cirrhosis: an evaluation of a modified scoring system. Am J Gastroenterol 2002;97:1191-1197.

145. Silveira MG, Talwalkar JA, Angulo P, Lindor KD. Overlap of autoimmune hepatitis and primary biliary cirrhosis: long-term outcomes. Am J Gastroenterol 2007:102:1244-1250.

146. Neuhauser M, Bjornsson E, Treeprasertsuk S, et al. Autoimmune hepatitis-PBC overlap syndrome: a simplified scoring system may assist in the diagnosis. Am J Gastroenterol 2010;105:345-353.

147. Fujiwara K, Yasui S, Tawada A, Fukuda Y, Nakano M, Yokosuka O. Diagnostic value and utility of the simplified International Autoimmune Hepatitis Group criteria in acute-onset autoimmune hepatitis. Liver Int 2011;31:1013-1020.

148. Homberg JC, Abuaf N, Bernard 0, et al. Chronic active hepatitis associated with antiliver/kidney microsome antibody type 1: a second type of "autoimmune" hepatitis. Hepatology 1987;7:13331339.

149. Czaja AJ, Manns MP, Homburger HA. Frequency and significance of antibodies to liver/kidney microsome type 1 in adults with chronic active hepatitis. Gastroenterology 1992;103:12902095.

150. Strettell MD, Donaldson PT, Thomson LJ, et al. Allelic basis for HLA-encoded susceptibility to type 1 autoimmune hepatitis. Gastroenterology 1997;112:2028-2035.

151. Czaja AJ, Kruger M, Santrach PJ, Moore SB, Manns MP. Genetic distinctions between types 1 and 2 autoimmune hepatitis. Am J Gastroenterol 1997;92:2197-2200.

152. Bittencourt PL, Goldberg AC, Cançado EL, et al. Genetic heterogeneity in susceptibility to autoimmune hepatitis types 1 and 2. Am J Gastroenterol 1999;94:1906-1913.

153. Djilali-Saiah I, Fakhfakh A, Louafi H, Caillat-Zucman S, Debray D, Alvarez F. HLA class II influences humoral autoimmunity in patients with type 2 autoimmune hepatitis. J Hepatol 2006;45:844850.

154. Czaja AJ, Manns MP. The validity and importance of subtypes in autoimmune hepatitis: a point of view. Am J Gastroenterol 1995;90:1206-1211.

155. Muratori P, Lalanne C, Fabbri A, Cassani F, Lenzi M, Muratori L. Type 1 and type 2 autoimmune hepatitis in adults share the same clinical phenotype. Aliment Pharmacol Ther 2015;41:1281-1287.

156. Czaja AJ. Performance parameters of the conventional serological markers for autoimmune hepatitis. Dig Dis Sci 2011;56:545-554.

157. Loria $\mathrm{P}$, Lonardo A, Leonardi F, et al. Non-organ-specific autoantibodies in nonalcoholic fatty liver disease: prevalence and correlates. Dig Dis Sci 2003;48:2173-2181.

158. Adams LA, Lindor KD, Angulo P. The prevalence of autoantibodies and autoimmune hepatitis in patients with nonalcoholic fatty liver disease. Am J Gastroenterol 2004;99:1316-1320.

159. Couto CA, Bittencourt PL, Porta G, et al. Antismooth muscle and antiactin antibodies are indirect markers of histological and biochemical activity of autoimmune hepatitis. Hepatology 2014;59:592-600.

160. Czaja AJ, Nishioka M, Morshed SA, Hachiya T. Patterns of nuclear immunofluorescence and reactivities to recombinant nuclear antigens in autoimmune hepatitis. Gastroenterology 1994;107:200-207.

161. Czaja AJ, Ming C, Shirai M, Nishioka M. Frequency and signifi- 
cance of antibodies to histones in autoimmune hepatitis. J Hepatol 1995;23:32-38.

162. Czaja AJ, Cassani F, Cataleta M, Valentini P, Bianchi FB. Frequency and significance of antibodies to actin in type 1 autoimmune hepatitis. Hepatology 1996;24:1068-1073.

163. Gregorio GV, Portmann B, Karani J, et al. Autoimmune hepatitis/ sclerosing cholangitis overlap syndrome in childhood: a 16-year prospective study. Hepatology 2001;33:544-553.

164. Reddy KR, Krawitt EL, Homberg JC, et al. Absence of anti-LKM-1 antibody in hepatitis C viral infection in the United States of America. J Viral Hepat 1995;2:175-179.

165. Abuaf N, Lunel F, Giral P, et al. Non-organ specific autoantibodies associated with chronic C virus hepatitis. J Hepatol 1993;18:359364.

166. Muratori P, Czaja AJ, Muratori L, et al. Evidence of a genetic basis for the different geographic occurrences of liver/kidney microsomal antibody type 1 in hepatitis C. Dig Dis Sci 2007;52:179184.

167. Manns MP, Griffin KJ, Sullivan KF, Johnson EF. LKM-1 autoantibodies recognize a short linear sequence in P450IID6, a cytochrome P-450 monooxygenase. J Clin Invest 1991;88:13701378.

168. Ma Y, Thomas MG, Okamoto M, et al. Key residues of a major cytochrome P4502D6 epitope are located on the surface of the molecule. J Immunol 2002;169:277-285.

169. Czaja AJ. Autoantibodies in autoimmune liver disease. Adv Clin Chem 2005;40:127-164.

170. Czaja AJ. The role of autoantibodies as diagnostic markers of autoimmune hepatitis. Expert Rev Clin Immunol 2006;2:33-48.

171. Czaja AJ, Norman GL. Autoantibodies in the diagnosis and management of liver disease. J Clin Gastroenterol 2003;37:315-329

172. Chretien-Leprince P, Ballot E, Andre C, et al. Diagnostic value of anti-F-actin antibodies in a French multicenter study. Ann N Y Acad Sci 2005;1050:266-273.

173. Frenzel C, Herkel J, Lüth S, Galle PR, Schramm C, Lohse AW. Evaluation of F-actin ELISA for the diagnosis of autoimmune hepatitis. Am J Gastroenterol 2006;101:2731-2736.

174. Granito A, Muratori L, Muratori P, et al. Antibodies to filamentous actin (F-actin) in type 1 autoimmune hepatitis. J Clin Pathol 2006;59:280-284

175. Martinez-Neira R, dos Remedios CG, Mackay IR. An actin-myosin functional assay for analysis of smooth muscle (anti-microfilament) autoantibodies in human plasma. J Immunol Methods 2008;338:63-66.

176. Soares A, Cunha R, Rodrigues F, Ribeiro H. Smooth muscle autoantibodies with F-actin specificity. Autoimmun Rev 2009;8:713716.

177. Czaja AJ, Manns MP. Advances in the diagnosis, pathogenesis, and management of autoimmune hepatitis. Gastroenterology 2010;139:58-72.e4.

178. Chan Y, Tong HQ, Beggs AH, Kunkel LM. Human skeletal musclespecific alpha-actinin-2 and -3 isoforms form homodimers and heterodimers in vitro and in vivo. Biochem Biophys Res Commun 1998;248:134-139.

179. Efe C, Ozaslan E, Wahlin S, et al. Antibodies to soluble liver antigen in patients with various liver diseases: a multicentre study. Liver Int 2013;33:190-196.

180. Ballot E, Homberg JC, Johanet C. Antibodies to soluble liver antigen: an additional marker in type 1 auto-immune hepatitis. $\mathrm{J}$ Hepatol 2000;33:208-215.

181. Czaja AJ, Carpenter HA, Manns MP. Antibodies to soluble liver antigen, P450IID6, and mitochondrial complexes in chronic hepatitis. Gastroenterology 1993;105:1522-1528.

182. Wies I, Brunner S, Henninger J, et al. Identification of target antigen for SLA/LP autoantibodies in autoimmune hepatitis. Lancet 2000;355:1510-1515.

183. Volkmann M, Luithle D, Zentgraf H, et al. SLA/LP/tRNP((Ser)Sec) antigen in autoimmune hepatitis: identification of the native protein in human hepatic cell extract. J Autoimmun 2010;34:59-65.

184. Schramm C, Herkel J, Beuers U, Kanzler S, Galle PR, Lohse AW. Pregnancy in autoimmune hepatitis: outcome and risk factors. Am J Gastroenterol 2006;101:556-560.

185. Liaskos C, Bogdanos DP, Rigopoulou EI, et al. Antibody responses specific for soluble liver antigen co-occur with Ro-52 autoantibodies in patients with autoimmune hepatitis (abstract). $\mathrm{J}$ Hepatol 2007;46(Suppl 1):S250.

186. Eyraud V, Chazouilleres O, Ballot E, Corpechot C, Poupon R, Johanet C. Significance of antibodies to soluble liver antigen/liver pancreas: a large French study. Liver Int 2009;29:857-864.

187. Mulder AH, Horst G, Haagsma EB, Limburg PC, Kleibeuker JH, Kallenberg CG. Prevalence and characterization of neutrophil cytoplasmic antibodies in autoimmune liver diseases. Hepatology 1993;17:411-417.

188. Bansi D, Chapman R, Fleming K. Antineutrophil cytoplasmic antibodies in chronic liver diseases: prevalence, titre, specificity and IgG subclass. J Hepatol 1996;24:581-586.

189. Terjung B, Söhne J, Lechtenberg B, et al. p-ANCAs in autoimmune liver disorders recognise human beta-tubulin isotype 5 and cross-react with microbial protein FtsZ. Gut 2010;59:808-816.

190. Zauli D, Ghetti S, Grassi A, et al. Anti-neutrophil cytoplasmic antibodies in type 1 and 2 autoimmune hepatitis. Hepatology 1997;25:1105-1107.

191. Terjung B, Spengler U, Sauerbruch T, Worman HJ. “Atypical pANCA" in IBD and hepatobiliary disorders react with a 50-kilodalton nuclear envelope protein of neutrophils and myeloid cell lines. Gastroenterology 2000;119:310-322.

192. Sobajima J, Ozaki S, Uesugi H, et al. High mobility group (HMG) non-histone chromosomal proteins HMG1 and HMG2 are significant target antigens of perinuclear anti-neutrophil cytoplasmic antibodies in autoimmune hepatitis. Gut 1999;44:867-873.

193. Elkayam 0, Levartovsky D, Brautbar C, et al. Clinical and immunological study of 7 patients with minocycline-induced autoimmune phenomena. Am J Med 1998;105:484-487.

194. Terjung B, Spengler U. Atypical p-ANCA in PSC and AIH: a hint 
toward a "leaky gut"? Clin Rev Allergy Immunol 2009;36:40-51.

195. Zachou K, Rigopoulou E, Dalekos GN. Autoantibodies and autoantigens in autoimmune hepatitis: important tools in clinical practice and to study pathogenesis of the disease. J Autoimmune Dis 2004;1:2.

196. Roozendaal C, de Jong MA, van den Berg AP, van Wijk RT, Limburg PC, Kallenberg CG. Clinical significance of anti-neutrophil cytoplasmic antibodies (ANCA) in autoimmune liver diseases. J Hepatol 2000;32:734-741.

197. Schwarze C, Terjung B, Lilienweiss P, et al. IgA class antineutrophil cytoplasmic antibodies in primary sclerosing cholangitis and autoimmune hepatitis. Clin Exp Immunol 2003;133:283-289.

198. McFarlane BM, McSorley CG, Vergani D, McFarlane IG, Williams R. Serum autoantibodies reacting with the hepatic asialoglycoprotein receptor protein (hepatic lectin) in acute and chronic liver disorders. J Hepatol 1986;3:196-205.

199. Treichel U, Poralla T, Hess G, Manns M, Meyer zum Büschenfelde $\mathrm{KH}$. Autoantibodies to human asialoglycoprotein receptor in autoimmune-type chronic hepatitis. Hepatology 1990;11:606-612.

200. Treichel U, McFarlane BM, Seki T, et al. Demographics of antiasialoglycoprotein receptor autoantibodies in autoimmune hepatitis. Gastroenterology 1994;107:799-804.

201. Czaja AJ, Pfeifer KD, Decker RH, Vallari AS. Frequency and significance of antibodies to asialoglycoprotein receptor in type 1 autoimmune hepatitis. Dig Dis Sci 1996;41:1733-1740.

202. Hajoui O, Debray D, Martin S, Alvarez F. Auto-antibodies to the asialoglycoprotein receptor in sera of children with auto-immune hepatitis. Eur J Pediatr 2000;159:310-313.

203. Husa P, Chalupa P, Stroblová H, Husová L, Slesinger P, Zajíc J. Autoantibodies to asialoglycoprotein receptor in chronic hepatitis C patients. Acta Virol 2001;45:7-11.

204. Yoshioka M, Mizuno M, Morisue Y, et al. Anti-asialoglycoprotein receptor autoantibodies, detected by a capture-immunoassay, are associated with autoimmune liver diseases. Acta Med Okayama 2002;56:99-105.

205. Johnson PJ, McFarlane IG, McFarlane BM, Williams R. Autoimmune features in patients with idiopathic chronic active hepatitis who are seronegative for conventional auto-antibodies. J Gastroenterol Hepatol 1990;5:244-251.

206. McFarlane IG, Hegarty JE, McSorley CG, McFarlane BM, Williams R. Antibodies to liver-specific protein predict outcome of treatment withdrawal in autoimmune chronic active hepatitis. Lancet 1984;2:954-956.

207. Roggenbuck D, Mytilinaiou MG, Lapin SV, Reinhold D, Conrad K. Asialoglycoprotein receptor (ASGPR): a peculiar target of liverspecific autoimmunity. Auto Immun Highlights 2012;3:119-125.

208. Muratori L, Cataleta M, Muratori P, Lenzi M, Bianchi FB. Liver/ kidney microsomal antibody type 1 and liver cytosol antibody type 1 concentrations in type 2 autoimmune hepatitis. Gut 1998; 42:721-726

209. Martini E, Abuaf N, Cavalli F, Durand V, Johanet C, Homberg JC. Antibody to liver cytosol (anti-LC1) in patients with autoimmune chronic active hepatitis type 2. Hepatology 1988;8:1662-1666.

210. Abuaf N, Johanet C, Chretien P, et al. Characterization of the liver cytosol antigen type 1 reacting with autoantibodies in chronic active hepatitis. Hepatology 1992;16:892-898.

211. Lenzi M, Manotti P, Muratori L, et al. Liver cytosolic 1 antigenantibody system in type 2 autoimmune hepatitis and hepatitis C virus infection. Gut 1995;36:749-754.

212. Ballot E, Desbos A, Monier JC. Detection on immunoblot of new proteins from the soluble fraction of the cell recognized either by anti-liver-kidney microsome antibodies type 1 or by anti-liver cytosol antibodies type 1: relationship with hepatitis $\mathrm{C}$ virus infection. Clin Immunol Immunopathol 1996;80(3 Pt 1):245-254.

213. Béland K, Lapierre P, Marceau G, Alvarez F. Anti-LC1 autoantibodies in patients with chronic hepatitis $\mathrm{C}$ virus infection. $\mathrm{J} \mathrm{Au}-$ toimmun 2004;22:159-166.

214. Rigopoulou EI, Mytilinaiou M, Romanidou 0, Liaskos C, Dalekos GN. Autoimmune hepatitis-specific antibodies against soluble liver antigen and liver cytosol type 1 in patients with chronic viral hepatitis. J Autoimmune Dis 2007;4:2.

215. Han S, Tredger M, Gregorio GV, Mieli-Vergani G, Vergani D. Anti-liver cytosolic antigen type 1 (LC1) antibodies in childhood autoimmune liver disease. Hepatology 1995;21:58-62.

216. Czaja AJ, Shums Z, Norman GL. Nonstandard antibodies as prognostic markers in autoimmune hepatitis. Autoimmunity 2004;37: 195-201.

217. Muratori L, Cataleta M, Muratori P, et al. Detection of anti-liver cytosol antibody type 1 (anti-LC1) by immunodiffusion, counterimmunoelectrophoresis and immunoblotting: comparison of different techniques. J Immunol Methods 1995;187:259-264.

218. Bridoux-Henno L, Maggiore G, Johanet C, et al. Features and outcome of autoimmune hepatitis type 2 presenting with isolated positivity for anti-liver cytosol antibody. Clin Gastroenterol Hepatol 2004;2:825-830.

219. Lapierre P, Hajoui O, Homberg JC, Alvarez F. Formiminotransferase cyclodeaminase is an organ-specific autoantigen recognized by sera of patients with autoimmune hepatitis. Gastroenterology 1999;116:643-649.

220. Muratori L, Sztul E, Muratori P, et al. Distinct epitopes on formiminotransferase cyclodeaminase induce autoimmune liver cytosol antibody type 1. Hepatology 2001;34:494-501.

221. Lapierre P, Johanet C, Alvarez F. Characterization of the B cell response of patients with anti-liver cytosol autoantibodies in type 2 autoimmune hepatitis. Eur J Immunol 2003;33:1869-1878.

222. Renous R, Lapierre P, Djilali-Saiah I, Vitozzi S, Alvarez F. Characterization of the antigenicity of the formiminotransferasecyclodeaminase in type 2 autoimmune hepatitis. Exp Cell Res 2004;292:332-341.

223. Summerskill WH, Korman MG, Ammon HV, Baggenstoss AH. Prednisone for chronic active liver disease: dose titration, standard dose, and combination with azathioprine compared. Gut 1975; 16:876-883.

224. Sandborn WJ. A review of immune modifier therapy for inflam- 
matory bowel disease: azathioprine, 6-mercaptopurine, cyclosporine, and methotrexate. Am J Gastroenterol 1996;91:423-433.

225. Allison AC. Immunosuppressive drugs: the first 50 years and a glance forward. Immunopharmacology 2000;47:63-83.

226. Rosenkrantz JG, Githens JH, Cox SM, Kellum DL. Azathioprine (Imuran) and pregnancy. Am J Obstet Gynecol 1967;97:387-394.

227. de Boer NK, Jarbandhan SV, de Graaf P, Mulder CJ, van Elburg RM, van Bodegraven AA. Azathioprine use during pregnancy: unexpected intrauterine exposure to metabolites. Am J Gastroenterol 2006;101:1390-1392.

228. Candia L, Marquez J, Espinoza LR. Autoimmune hepatitis and pregnancy: a rheumatologist's dilemma. Semin Arthritis Rheum 2005;35:49-56.

229. Heneghan MA, Norris SM, O'Grady JG, Harrison PM, McFarlane IG. Management and outcome of pregnancy in autoimmune hepatitis. Gut 2001;48:97-102.

230. Francella A, Dyan A, Bodian C, Rubin P, Chapman M, Present $\mathrm{DH}$. The safety of 6-mercaptopurine for childbearing patients with inflammatory bowel disease: a retrospective cohort study. Gastroenterology 2003;124:9-17.

231. Werner M, Björnsson E, Prytz H, et al. Autoimmune hepatitis among fertile women: strategies during pregnancy and breastfeeding? Scand J Gastroenterol 2007;42:986-991.

232. Akbari M, Shah S, Velayos FS, Mahadevan U, Cheifetz AS. Systematic review and meta-analysis on the effects of thiopurines on birth outcomes from female and male patients with inflammatory bowel disease. Inflamm Bowel Dis 2013;19:15-22.

233. Casanova MJ, Chaparro M, Domènech E, et al. Safety of thiopurines and anti-TNF-alpha drugs during pregnancy in patients with inflammatory bowel disease. Am J Gastroenterol 2013;108:433-440.

234. Kanzler S, Löhr H, Gerken G, Galle PR, Lohse AW. Long-term management and prognosis of autoimmune hepatitis (AIH): a single center experience. Z Gastroenterol 2001;39:339-341, 344338.

235. Kanzler S, Gerken G, Löhr H, Galle PR, Meyer zum Büschenfelde $\mathrm{KH}$, Lohse AW. Duration of immunosuppressive therapy in autoimmune hepatitis. J Hepatol 2001;34:354-355.

236. Sahasranaman S, Howard D, Roy S. Clinical pharmacology and pharmacogenetics of thiopurines. Eur J Clin Pharmacol 2008;64:753-767.

237. Ben Ari Z, Mehta A, Lennard L, Burroughs AK. Azathioprineinduced myelosuppression due to thiopurine methyltransferase deficiency in a patient with autoimmune hepatitis. J Hepatol 1995;23:351-354.

238. Langley PG, Underhill J, Tredger JM, Norris S, McFarlane IG. Thiopurine methyltransferase phenotype and genotype in relation to azathioprine therapy in autoimmune hepatitis. J Hepatol 2002;37:441-447.

239. Heneghan MA, Allan ML, Bornstein JD, Muir AJ, Tendler DA Utility of thiopurine methyltransferase genotyping and phenotyping, and measurement of azathioprine metabolites in the management of patients with autoimmune hepatitis. J Hepatol 2006;45:584-591.

240. Czaja AJ, Carpenter HA. Thiopurine methyltransferase deficiency and azathioprine intolerance in autoimmune hepatitis. Dig Dis Sci 2006;51:968-975.

241. Montano-Loza AJ, Carpenter HA, Czaja AJ. Improving the end point of corticosteroid therapy in type 1 autoimmune hepatitis to reduce the frequency of relapse. Am J Gastroenterol 2007;102:1005-1012.

242. Czaja AJ. Rapidity of treatment response and outcome in type 1 autoimmune hepatitis. J Hepatol 2009;51:161-167.

243. Czaja AJ, Wolf AM, Baggenstoss AH. Laboratory assessment of severe chronic active liver disease during and after corticosteroid therapy: correlation of serum transaminase and gamma globulin levels with histologic features. Gastroenterology 1981;80:687692.

244. Czaja AJ. Review article: permanent drug withdrawal is desirable and achievable for autoimmune hepatitis. Aliment Pharmacol Ther 2014;39:1043-1058.

245. Czaja AJ, Davis GL, Ludwig J, Taswell HF. Complete resolution of inflammatory activity following corticosteroid treatment of HBsAg-negative chronic active hepatitis. Hepatology 1984;4:622627.

246. Czaja AJ, Menon KV, Carpenter HA. Sustained remission after corticosteroid therapy for type 1 autoimmune hepatitis: a retrospective analysis. Hepatology 2002;35:890-897.

247. van Gerven NM, Verwer BJ, Witte BI, et al. Relapse is almost universal after withdrawal of immunosuppressive medication in patients with autoimmune hepatitis in remission. J Hepatol 2013;58:141-147.

248. Czaja AJ, Beaver SJ, Shiels MT. Sustained remission after corticosteroid therapy of severe hepatitis B surface antigen-negative chronic active hepatitis. Gastroenterology 1987;92:215-219.

249. Czaja AJ, Ammon HV, Summerskill WH. Clinical features and prognosis of severe chronic active liver disease (CALD) after corticosteroid-induced remission. Gastroenterology 1980;78:518-523.

250. Hegarty JE, Nouri Aria KT, Portmann B, Eddleston AL, Williams R. Relapse following treatment withdrawal in patients with autoimmune chronic active hepatitis. Hepatology 1983;3:685-689.

251. Montano-Loza AJ, Carpenter HA, Czaja AJ. Consequences of treatment withdrawal in type 1 autoimmune hepatitis. Liver Int 2007;27:507-515.

252. Montano-Loza AJ, Carpenter HA, Czaja AJ. Features associated with treatment failure in type 1 autoimmune hepatitis and predictive value of the model of end-stage liver disease. Hepatology 2007;46:1138-1145.

253. Selvarajah V, Montano-Loza AJ, Czaja AJ. Systematic review: managing suboptimal treatment responses in autoimmune hepatitis with conventional and nonstandard drugs. Aliment Pharmacol Ther 2012;36:691-707.

254. Czaja AJ. Safety issues in the management of autoimmune hepatitis. Expert Opin Drug Saf 2008;7:319-333. 
255. Bajaj JS, Saeian K, Varma RR, et al. Increased rates of early adverse reaction to azathioprine in patients with Crohn's disease compared to autoimmune hepatitis: a tertiary referral center experience. Am J Gastroenterol 2005;100:1121-1125.

256. Czaja AJ. Management of recalcitrant autoimmune hepatitis. Curr Hepatitis Rep 2013;12:66-77.

257. Schalm SW, Ammon HV, Summerskill WH. Failure of customary treatment in chronic active liver disease: causes and management. Ann Clin Res 1976;8:221-227.

258. Seela S, Sheela H, Boyer JL. Autoimmune hepatitis type 1: safety and efficacy of prolonged medical therapy. Liver Int 2005;25:734739.

259. Czaja AJ. Low-dose corticosteroid therapy after multiple relapses of severe HBsAg-negative chronic active hepatitis. Hepatology 1990;11:1044-1049.

260. Allison AC, Eugui EM. Mycophenolate mofetil and its mechanisms of action. Immunopharmacology 2000;47:85-118.

261. Allison AC. Mechanisms of action of mycophenolate mofetil. Lupus 2005;14 Suppl 1:S2-S8.

262. Perez-Aytes A, Ledo A, Boso V, et al. In utero exposure to mycophenolate mofetil: a characteristic phenotype? Am J Med Genet A 2008;146:1-7.

263. Anderka MT, Lin AE, Abuelo DN, Mitchell AA, Rasmussen SA. Reviewing the evidence for mycophenolate mofetil as a new teratogen: case report and review of the literature. Am J Med Genet A 2009;149:1241-1248.

264. Klieger-Grossmann C, Chitayat D, Lavign S, et al. Prenatal exposure to mycophenolate mofetil: an updated estimate. J Obstet Gynaecol Can 2010;32:794-797.

265. Lin AE, Singh KE, Strauss A, Nguyen S, Rawson K, Kimonis VE. An additional patient with mycophenolate mofetil embryopathy: cardiac and facial analyses. Am J Med Genet A 2011;155:748756.

266. Woynarowski M, Nemeth A, Baruch Y, et al. Budesonide versus prednisone with azathioprine for the treatment of autoimmune hepatitis in children and adolescents. J Pediatr 2013;163:13471353.e1.

267. Mieli-Vergani G, Vergani D. Budesonide for juvenile autoimmune hepatitis? Not yet. J Pediatr 2013;163:1246-1248.

268. Geier A, Gartung C, Dietrich CG, Wasmuth HE, Reinartz P, Matern S. Side effects of budesonide in liver cirrhosis due to chronic autoimmune hepatitis: influence of hepatic metabolism versus portosystemic shunts on a patient complicated with HCC. World J Gastroenterol 2003;9:2681-2685.

269. Efe C, Ozaslan E, Kav T, et al. Liver fibrosis may reduce the efficacy of budesonide in the treatment of autoimmune hepatitis and overlap syndrome. Autoimmun Rev 2012;11:330-334.

270. Lohse AW, Gil H. Reactivation of autoimmune hepatitis during budesonide monotherapy, and response to standard treatment. J Hepatol 2011;54:837-839.

271. Czaja AJ, Lindor KD. Failure of budesonide in a pilot study of treatment-dependent autoimmune hepatitis. Gastroenterology
2000;119:1312-1316.

272. Czaja AJ. Mycophenolate mofetil to the rescue in autoimmune hepatitis: a fresh sprout on the decision tree. J Hepatol 2009;51:810

273. Seikaly MG. Mycophenolate mofetil: is it worth the cost? The infavor opinion. Pediatr Transplant 1999;3:79-82.

274. Alvarez F, Ciocca M, Cañero-Velasco C, et al. Short-term cyclosporine induces a remission of autoimmune hepatitis in children. J Hepatol 1999;30:222-227.

275. Cuarterolo M, Ciocca M, Velasco CC, et al. Follow-up of children with autoimmune hepatitis treated with cyclosporine. J Pediatr Gastroenterol Nutr 2006;43:635-639.

276. Larsen FS, Vainer B, Eefsen M, Bjerring PN, Adel Hansen B. Lowdose tacrolimus ameliorates liver inflammation and fibrosis in steroid refractory autoimmune hepatitis. World J Gastroenterol 2007;13:3232-3236.

277. Hess AD, Fischer AC, Horwitz LR, Laulis MK. Cyclosporineinduced autoimmunity: critical role of autoregulation in the prevention of major histocompatibility class II-dependent autoaggression. Transplant Proc 1993;25:2811-2813.

278. Lohse AW, Weiler-Norman C, Burdelski M. De novo autoimmune hepatitis after liver transplantation. Hepatol Res 2007;37 Suppl 3:S462.

279. Chatur N, Ramji A, Bain VG, et al. Transplant immunosuppressive agents in non-transplant chronic autoimmune hepatitis: the Canadian association for the study of liver (CASL) experience with mycophenolate mofetil and tacrolimus. Liver Int 2005;25:723727.

280. Kerkar N, Dugan C, Rumbo C, et al. Rapamycin successfully treats post-transplant autoimmune hepatitis. Am J Transplant 2005;5:1085-1089.

281. Santos ES, Arosemena LR, Raez LE, O'Brien C, Regev A. Successful treatment of autoimmune hepatitis and idiopathic thrombocytopenic purpura with the monoclonal antibody, rituximab: case report and review of literature. Liver Int 2006;26:625-629.

282. Evans JT, Shepard MM, Oates JC, Self SE, Reuben A. Rituximabresponsive cryoglobulinemic glomerulonephritis in a patient with autoimmune hepatitis. J Clin Gastroenterol 2008;42:862-863.

283. Barth E, Clawson J. A case of autoimmune hepatitis treated with rituximab. Case Rep Gastroenterol 2010;4:502-509.

284. Carey EJ, Somaratne K, Rakela J. Successful rituximab therapy in refractory autoimmune hepatitis and Evans syndrome. Rev Med Chil 2011;139:1484-1487.

285. Burak KW, Swain MG, Santodomingo-Garzon T, et al. Rituximab for the treatment of patients with autoimmune hepatitis who are refractory or intolerant to standard therapy. Can J Gastroenterol 2013;27:273-280.

286. Germano V, Picchianti Diamanti A, Baccano G, et al. Autoimmune hepatitis associated with infliximab in a patient with psoriatic arthritis. Ann Rheum Dis 2005;64:1519-1520.

287. Marques M, Magro F, Cardoso H, et al. Infliximab-induced lupuslike syndrome associated with autoimmune hepatitis. Inflamm 
Bowel Dis 2008;14:723-725.

288. Fairhurst DA, Sheehan-Dare R. Autoimmune hepatitis associated with infliximab in a patient with palmoplantar pustular psoriaisis. Clin Exp Dermatol 2009;34:421-422.

289. Ghabril M, Bonkovsky HL, Kum C, et al. Liver injury from tumor necrosis factor-alpha antagonists: analysis of thirty-four cases. Clin Gastroenterol Hepatol 2013;11:558-564.e3.

290. Dulai PS, Thompson KD, Blunt HB, Dubinsky MC, Siegel CA. Risks of serious infection or lymphoma with anti-tumor necrosis factor therapy for pediatric inflammatory bowel disease: a systematic review. Clin Gastroenterol Hepatol 2014;12:1443-1451.

291. Björnsson ES, Gunnarsson BI, Gröndal G, et al. Risk of druginduced liver injury from tumor necrosis factor antagonists. Clin Gastroenterol Hepatol 2015;13:602-608.

292. Núñez-Martínez 0, De la Cruz G, Salcedo M, et al. Liver transplantation for autoimmune hepatitis: fulminant versus chronic hepatitis presentation. Transplant Proc 2003;35:1857-1858.

293. Tripathi D, Neuberger J. Autoimmune hepatitis and liver transplantation: indications, results, and management of recurrent disease. Semin Liver Dis 2009;29:286-296.

294. Neuberger J. Transplantation for autoimmune hepatitis. Semin Liver Dis 2002;22:379-386.

295. Martin SR, Alvarez F, Anand R, Song C, Yin W; SPLIT Research Group. Outcomes in children who underwent transplantation for autoimmune hepatitis. Liver Transpl 2011;17:393-401.

296. Birnbaum AH, Benkov KJ, Pittman NS, McFarlane-Ferreira Y, Rosh JR, LeLeiko NS. Recurrence of autoimmune hepatitis in children after liver transplantation. J Pediatr Gastroenterol Nutr 1997;25:20-25

297. Milkiewicz P, Hubscher SG, Skiba G, Hathaway M, Elias E. Recurrence of autoimmune hepatitis after liver transplantation. Transplantation 1999;68:253-256.

298. Reich DJ, Fiel I, Guarrera JV, et al. Liver transplantation for autoimmune hepatitis. Hepatology 2000;32(4 Pt 1):693-700.

299. Yusoff IF, House AK, De Boer WB, et al. Disease recurrence after liver transplantation in Western Australia. J Gastroenterol Hepatol 2002;17:203-207.

300. Czaja AJ. Nonstandard drugs and feasible new interventions for autoimmune hepatitis. Part II. Inflamm Allergy Drug Targets 2012;11:351-363.

301. Chen M, Su W, Lin X, et al. Adoptive transfer of human gingivaderived mesenchymal stem cells ameliorates collagen-induced arthritis via suppression of Th1 and Th17 cells and enhancement of regulatory T cell differentiation. Arthritis Rheum 2013;65:11811193.

302. Scalapino KJ, Daikh DI. CTLA-4: a key regulatory point in the control of autoimmune disease. Immunol Rev 2008;223:143-155.

303. Dhirapong A, Yang GX, Nadler S, et al. Therapeutic effect of cytotoxic T lymphocyte antigen 4/immunoglobulin on a murine model of primary biliary cirrhosis. Hepatology 2013;57:708-715.

304. Smith CA, Williams GT, Kingston R, Jenkinson EJ, Owen JJ. Antibodies to CD3/T-cell receptor complex induce death by apopto- sis in immature T cells in thymic cultures. Nature 1989;337:181184.

305. Perruche S, Zhang P, Liu Y, Saas P, Bluestone JA, Chen W. CD3specific antibody-induced immune tolerance involves transforming growth factor-beta from phagocytes digesting apoptotic $\mathrm{T}$ cells. Nat Med 2008;14:528-535.

306. Ochi $\mathrm{H}$, Abraham M, Ishikawa $\mathrm{H}$, et al. New immunosuppressive approaches: oral administration of $\mathrm{CD} 3$-specific antibody to treat autoimmunity. J Neurol Sci 2008;274:9-12.

307. Chatenoud L, Thervet E, Primo J, Bach JF. Anti-CD3 antibody induces long-term remission of overt autoimmunity in nonobese diabetic mice. Proc Natl Acad Sci U S A 1994;91:123-127.

308. Herold KC, Hagopian W, Auger JA, et al. Anti-CD3 monoclonal antibody in new-onset type 1 diabetes mellitus. N Engl J Med 2002;346:1692-1698.

309. Longhi MS, Ma Y, Bogdanos DP, Cheeseman P, Mieli-Vergani G, Vergani D. Impairment of CD4(+)CD25(+) regulatory T-cells in autoimmune liver disease. J Hepatol 2004;41:31-37.

310. Longhi MS, Hussain MJ, Mitry RR, et al. Functional study of CD4+CD25+ regulatory $T$ cells in health and autoimmune hepatitis. J Immunol 2006;176:4484-4491.

311. Peiseler M, Sebode M, Franke B, et al. FOXP3+ regulatory T cells in autoimmune hepatitis are fully functional and not reduced in frequency. J Hepatol 2012;57:125-132.

312. Kido M, Watanabe N, Okazaki T, et al. Fatal autoimmune hepatitis induced by concurrent loss of naturally arising regulatory $\mathrm{T}$ cells and PD-1-mediated signaling. Gastroenterology 2008;135:13331343.

313. Tanaka H, Zhang W, Yang GX, et al. Successful immunotherapy of autoimmune cholangitis by adoptive transfer of forkhead box protein 3(+) regulatory T cells. Clin Exp Immunol 2014;178:253261.

314. Novak J, Lehuen A. Mechanism of regulation of autoimmunity by iNKT cells. Cytokine 2011;53:263-270.

315. Van Kaer L, Parekh VV, Wu L. Invariant NK T cells: potential for immunotherapeutic targeting with glycolipid antigens. Immunotherapy 2011;3:59-75.

316. Dennert G, Aswad F. The role of NKT cells in animal models of autoimmune hepatitis. Crit Rev Immunol 2006;26:453-473.

317. Kawamura H, Aswad F, Minagawa M, Govindarajan S, Dennert G. P2X7 receptors regulate NKT cells in autoimmune hepatitis. J Immunol 2006;176:2152-2160.

318. Francois S, Mouiseddine M, Allenet-Lepage B, et al. Human mesenchymal stem cells provide protection against radiation-induced liver injury by antioxidative process, vasculature protection, hepatocyte differentiation, and trophic effects. Biomed Res Int 2013;2013:151679.

319. Ringdén 0, Uzunel M, Rasmusson I, et al. Mesenchymal stem cells for treatment of therapy-resistant graft-versus-host disease. Transplantation 2006;81:1390-1397.

320. Voswinkel J, Francois S, Simon JM, et al. Use of mesenchymal stem cells (MSC) in chronic inflammatory fistulizing and fibrotic 
diseases: a comprehensive review. Clin Rev Allergy Immunol 2013;45:180-192.

321. Peng Y, Ke M, Xu L, et al. Donor-derived mesenchymal stem cells combined with low-dose tacrolimus prevent acute rejection after renal transplantation: a clinical pilot study. Transplantation 2013;95:161-168.

322. Czaja AJ. Review article: the prevention and reversal of hepatic fibrosis in autoimmune hepatitis. Aliment Pharmacol Ther 2014;39:385-406.

323. Czaja AJ. Hepatic inflammation and progressive liver fibrosis in chronic liver disease. World J Gastroenterol 2014;20:2515-2532.

324. Sanyal AJ, Chalasani N, Kowdley KV, et al. Pioglitazone, vitamin E, or placebo for nonalcoholic steatohepatitis. N Engl J Med 2010;362:1675-1685.

325. Harrison SA, Torgerson S, Hayashi P, Ward J, Schenker S. Vitamin $\mathrm{E}$ and vitamin $\mathrm{C}$ treatment improves fibrosis in patients with nonalcoholic steatohepatitis. Am J Gastroenterol 2003;98:24852490.

326. Mato JM, Cámara J, Fernández de Paz J, et al. S-adenosylmethionine in alcoholic liver cirrhosis: a randomized, placebocontrolled, double-blind, multicenter clinical trial. J Hepatol 1999;30:1081-1089.

327. Feld JJ, Modi AA, El-Diwany R, et al. S-adenosyl methionine improves early viral responses and interferon-stimulated gene induction in hepatitis C nonresponders. Gastroenterology 2011; 140:830-839.

328. Colmenero J, Bataller R, Sancho-Bru P, et al. Effects of losartan on hepatic expression of nonphagocytic NADPH oxidase and fibrogenic genes in patients with chronic hepatitis C. Am J Physiol Gastrointest Liver Physiol 2009;297:G726-G734.

329. Sanz-Cameno P, Medina J, García-Buey L, et al. Enhanced intrahepatic inducible nitric oxide synthase expression and nitrotyrosine accumulation in primary biliary cirrhosis and autoimmune hepatitis. J Hepatol 2002;37:723-729.

330. Pemberton PW, Aboutwerat A, Smith A, Burrows PC, McMahon RF, Warnes TW. Oxidant stress in type I autoimmune hepatitis: the link between necroinflammation and fibrogenesis? Biochim Biophys Acta 2004;1689:182-189.

331. Singal AK, Jampana SC, Weinman SA. Antioxidants as therapeutic agents for liver disease. Liver Int 2011;31:1432-1448.

332. Moreno-Otero R. May oxidative stress contribute to autoimmune hepatitis pathogenesis, and can antioxidants be of value as adjuvant therapy for refractory patients? Dig Dis Sci 2013;58:14401441.

333. Ueno Y, Ohmi T, Yamamoto M, et al. Orally-administered caspase inhibitor PF-03491390 is retained in the liver for prolonged periods with low systemic exposure, exerting a hepatoprotective effect against alpha-fas-induced liver injury in a mouse model. J Pharmacol Sci 2007;105:201-205.

334. Canbay A, Feldstein A, Baskin-Bey E, Bronk SF, Gores GJ. The caspase inhibitor IDN-6556 attenuates hepatic injury and fibrosis in the bile duct ligated mouse. J Pharmacol Exp Ther 2004;308:1191-1196.

335. Anstee QM, Concas D, Kudo H, et al. Impact of pan-caspase inhibition in animal models of established steatosis and nonalcoholic steatohepatitis. J Hepatol 2010;53:542-550.

336. Yoshida N, Iwata H, Yamada T, et al. Improvement of the survival rate after rat massive hepatectomy due to the reduction of apoptosis by caspase inhibitor. J Gastroenterol Hepatol 2007;22:20152021.

337. Pockros PJ, Schiff ER, Shiffman ML, et al. Oral IDN-6556, an antiapoptotic caspase inhibitor, may lower aminotransferase activity in patients with chronic hepatitis C. Hepatology 2007;46:324329.

338. Arends JE, Hoepelman AI, Nanlohy NM, et al. Low doses of the novel caspase-inhibitor GS-9450 leads to lower caspase-3 and -8 expression on peripheral CD4+ and CD8+ T-cells. Apoptosis 2011;16:959-966.

339. Faubel S, Edelstein CL. Caspases as drug targets in ischemic organ injury. Curr Drug Targets Immune Endocr Metabol Disord 2005;5:269-287.

340. Petta S, Cammà C, Scazzone C, et al. Low vitamin D serum level is related to severe fibrosis and low responsiveness to interferonbased therapy in genotype 1 chronic hepatitis C. Hepatology 2010;51:1158-1167.

341. Farnik H, Bojunga J, Berger A, et al. Low vitamin D serum concentration is associated with high levels of hepatitis B virus replication in chronically infected patients. Hepatology 2013;58:12701276.

342. Trépo E, Ouziel R, Pradat P, et al. Marked 25-hydroxyvitamin D deficiency is associated with poor prognosis in patients with alcoholic liver disease. J Hepatol 2013;59:344-350.

343. Efe C, Kav T, Aydin C, et al. Low serum vitamin D levels are associated with severe histological features and poor response to therapy in patients with autoimmune hepatitis. Dig Dis Sci 2014;59:3035-3042.

344. Beyazit Y, Kocak E, Tanoglu A, Kekilli M. Oxidative stress might play a role in low serum vitamin D associated liver fibrosis among patients with autoimmune hepatitis. Dig Dis Sci 2015;60:1106-1108

345. Dasarathy J, Periyalwar P, Allampati S, et al. Hypovitaminosis D is associated with increased whole body fat mass and greater severity of non-alcoholic fatty liver disease. Liver Int 2014;34:e118e127.

346. Arnson Y, Amital H, Shoenfeld Y. Vitamin D and autoimmunity: new aetiological and therapeutic considerations. Ann Rheum Dis 2007;66:1137-1142.

347. Codoñer-Franch P, Tavárez-Alonso S, Simó-Jordá R, LaportaMartín P, Carratalá-Calvo A, Alonso-Iglesias E. Vitamin D status is linked to biomarkers of oxidative stress, inflammation, and endothelial activation in obese children. J Pediatr 2012;161:848854. 
348. Smyk DS, Orfanidou T, Invernizzi P, Bogdanos DP, Lenzi M. Vitamin D in autoimmune liver disease. Clin Res Hepatol Gastroenterol 2013;37:535-545.
349. Czaja AJ. Transitioning from idiopathic to explainable autoimmune hepatitis. Dig Dis Sci 2015;60:2881-2900. 